\title{
ARTÍCULOS
}

\section{REVOLUCIONARIOS, INTERNACIONALISTAS Y SOBREVIVIENTES. UNA HISTORIA ORAL DE LA REVOLUCIÓN CUBANA'.}

\author{
Óscar López-Acón \\ Universidad de Zaragoza \\ olacon@unizar.es
}

\begin{abstract}
Resumen: La Revolución cubana constituye probablemente el hecho más influyente en la historia contemporánea de América Latina por su alcance y significado. Todavía hoy, los ecos de aquel acontecimiento se proyectan sobremanera en el presente y los numerosos interrogantes que sigue generando lo convierten en un terreno extraordinariamente fértil para su estudio. En el presente artículo queremos explorar las potencialidades que ofrece la historia oral para tal fin. Para ello, nos servimos de las historias de vida de algunos sujetos que tuvieron experiencia directa o participaron del acontecer político y social de Cuba desde la década de los cincuenta hasta el presente en distintos escenarios. El rescate de sus voces nos permite acercarnos a la experiencia vivida de la Revolución y nos ayuda a comprender el significado mismo de ese proceso histórico.
\end{abstract}

Palabras clave: Revolución cubana, historia oral, relatos de vida, historia del presente.

Tittle: REVOLUTIONARIES, INTERNATIONALIST AND SURVIVING. AN ORAL HISTORY OF THE CUBAN REVOLUTION.

Abstract: The Cuban Revolution constitute probably the most influential event in the contemporary history of Latin America due to its scope and significance. Even today, the echoes of that historical event are projected greatly in the present and the numerous of unanswered questions that still generate turn into extraordinary field to this study. In the present article we want to explore the potentialities what the oral history can offer us to reach that objective. In order to dive into this issue we shall focus in the life stories of some person who had direct experience or taken part in political and social happen in Cuba, from fifties decade to the present in a different scenes. The rescue of their voices allows us to approach the "lived experience" of the Revolution and helps us to know the very meaning of that historical process.

\footnotetext{
${ }^{1}$ El presente trabajo ha sido desarrollado en el marco de un contrato predoctoral del Departamento de Innovación, Investigación y Universidad del Gobierno de Aragón y Programa Operativo FSE Aragón 2014-2020. Constituye un producto del trabajo que acometimos en nuestra estancia de investigación en la Universidad de La Habana (Cuba), siendo beneficiarios de la beca de investigación de la Cátedra José Martí de la Facultad de Filosofía y Letras de la Universidad de Zaragoza en el año de 2019. Quisiera expresar un agradecimiento a todas las personas que accedieron a ser entrevistadas. Igualmente, por la inestimable ayuda prestada, a los profesores de la Universidad de La Habana Dr. Edelberto Leiva Lajara y Dr. Sergio Guerra Vilaboy, también al Director del Centro de Estudios Martianos, el Dr. Pedro Pablo Rodríguez López, y a la profesora del área de América del Departamento de Historia de la Universidad de Zaragoza Dra. Palmira Vélez Jiménez, así como a la Dra. Carmen Frías Corredor.
}

Recibido: 05-04-2021

Aceptado: 08-04-2021

Cómo citar este artículo: LÓPEZ-ACÓN, Óscar. Revolucionarios, internacionalistas y sobrevivientes. Una historia oral de la Revolución cubana. Naveg@mérica. Revista electrónica editada por la Asociación Española de Americanistas [en línea]. 2021, n. 27. Disponible en: $<$ http://revistas.um.es/navegamerica $>$. [Consulta: Fecha de consulta]. ISSN 1989-211X. 
Keywords: Cuban Revolution, oral history, life stories, present time history.

«Examiné todas estas cosas, y cómo los hombres luchan y pierden la batalla, y aquello por lo que lucharon tiene lugar pese a su derrota, y cuando llega resulta ser distinto a lo que ellos se proponían, y otros hombres tienen que luchar por lo que ellos se proponían bajo otro nombre...».

$$
\text { William Morris }{ }^{2}
$$

\section{Introducción}

La Revolución cubana constituye probablemente el hecho más influyente en la historia contemporánea de América Latina por su alcance y significado ${ }^{3}$. El "acontecimiento cardinal de América», en palabras de Ernesto Che Guevara ${ }^{4}$. Sin duda, la Revolución alteró los equilibrios de poder y abrió una nueva etapa en el continente latinoamericano con la emergencia y el desarrollo de luchas sociales y movimientos de liberación nacional. Para los sectores progresistas se convirtió en un ejemplo al que mirar con esperanza; en un modelo de cambio social para salir del secular atraso y dependencia neocolonial bajo la égida de la construcción del socialismo ${ }^{5}$. Todavía hoy, los ecos de aquel acontecimiento se proyectan sobremanera en el presente, y los numerosos interrogantes que dicho proceso histórico sigue generando lo convierten en un terreno extraordinariamente fértil para su estudio. En el presente artículo queremos explorar las potencialidades que ofrece la historia oral para tal fin. Para ello, nos servimos de las historias de vida de algunos sujetos que tuvieron experiencia directa o participaron del acontecer político y social de Cuba desde la década de los cincuenta hasta el presente en distintos escenarios $^{6}$. El rescate de sus voces permite recorrer nuevas vías en aras de la comprensión de la historia social del proceso revolucionario; pero, al mismo tiempo, los testimonios nos introducen en el complejo terreno de la memoria y nos permiten

\footnotetext{
${ }^{2}$ Cit. por: THOMPSON, Edward P. Miseria de la teoría. Barcelona: Crítica, 1981 [1978], p. 146.

${ }^{3}$ ALCÁZAR GARRIDO, Joan del (ed.). Historia actual de América latina 1959-2009. Valencia: Tirant lo Blanch, 2011, p. 9.
}

${ }^{4}$ GUEVARA, Ernesto Che. Cuba: ¿Excepción histórica o vanguardia en la lucha anticolonialista? En: GUEVARA, Ernesto Che. Mis sueños no tendrán fronteras. Compilación de María del Carmen Ariet García. La Habana: Centro de Estudios Che Guevara, 2011, p. 125 [publicado originalmente en la Revista Verde Olivo el 9 de abril de 1961].

${ }^{5}$ MARTÍN ÁLVAREZ, Alberto y REY TRISTÁN, Eduardo. La oleada revolucionaria latinoamericana contemporánea, 1959-1996. Definición, caracterización y algunas claves para su análisis. Naveg@mérica. Revista electrónica de la Asociación Española de Americanistas [en línea]. 2012, n. 9, pp. 1-36. [Fecha de consulta: 30-08-2020]. Disponible en $<$ https://revistas.um.es/navegamerica/article/view/161591/141091>; GUERRA VILABOY, Sergio. Las revoluciones latinoamericanas del siglo XX desde la historia comparada. SÉMATA. 2016, n. 28, pp. 299-319.

${ }^{6}$ El contacto con ellos se hizo a través del principio conocido como "bola de nieve" por medio del cual los individuos que aceptaban ser entrevistados contactaban con otros de su entorno. Mediante entrevistas semi-estructuradas y enunciando preguntas abiertas a nuestros ocho interlocutores, compilamos un volumen aproximado de veinte horas de grabaciones. A nivel metodológico, véase BARELA, Liliana; MIGUEZ, Mercedes y GARCÍA CONDE Luis. Algunos apuntes sobre historia oral. Buenos Aires: Instituto Histórico de la Ciudad de Buenos Aires, 2004; FOLGUERA, Pilar. Cómo se hace historia oral. Madrid: Eudema, 1994. 
aprehender un determinado discurso social $^{7}$ de la Revolución cubana, por lo que encierran un enorme caudal hermenéutico.

La historia oral constituye un terreno valioso y poco explorado para el caso cubano, tanto con respecto a personalidades y figuras influyentes, como a la gente común, «sin historia», como señala Rainer Schultz ${ }^{8}$. Uno de los primeros grandes proyectos de historia oral cubana corresponde al antropólogo americano Oscar Lewis, que llevó a cabo un estudio a finales de los años sesenta con objeto de analizar las transformaciones que se estaban produciendo en la nueva sociedad revolucionaria a través de los testimonios de sus protagonistas. Interesado en aplicar su particular metodología de estudio de familias, como la que había desarrollado en su influyente obra Los hijos de Sánchez (1961), él y su equipo recogieron una valiosa información acerca de como la Revolución había cambiado todos los aspectos de la vida de la gente de extracción social marginal de Las Yaguas, una antigua barriada pobre de La Habana ${ }^{9}$. Las historias de vida aportaban elementos para comprender el impacto de las nuevas instituciones, sus valores culturales, además de todos los conflictos y esperanzas desencadenadas. En la misma línea, Elizabeth Dore dirigió entre los años 2004 y 2015 el proyecto de investigación "Voces Cubanas" con objeto de historiar a la "gente corriente» y examinar la memoria social en el transcurso de los más de cincuenta años de vida de la Revolución ${ }^{10}$.

Recientemente, investigadores de la Universidad de La Habana y de la Universidad de Utrecht han desarrollado el programa "FLACSO-Cuba", con el título de "Las consecuencias para Cuba de la desaparición del socialismo europeo", llevando a cabo un acercamiento vivencial a la etapa más difícil que ha atravesado la sociedad cubana. Por medio de un debate grupal, dieciocho personas de distintos estratos profesionales y grupos de edades han divulgado sus vivencias y reflexiones en torno a este periodo, recogiendo tanto los procesos políticos en los que participaron como los factores explicativos de la desaparición del campo socialista y la resistencia de la sociedad cubana ${ }^{11}$. Por su parte, el historiador Dirk Kruijt ha alumbrado una obra con claro afán totalizador que reconstruye la experiencia de la generación revolucionaria cubana desde la lucha insurreccional contra Batista, hasta el internacionalismo cubano en América Latina y el Caribe durante las siguientes cinco décadas. De igual modo, las fuentes orales han revelado su extraordinario potencial en los trabajos de Manuel Ramírez Chicharro, que estudia la participación

\footnotetext{
${ }^{7}$ La noción de «discurso social», en ROBIN, Regine. ¿Cede la historia oral la palabra a quienes están privados de ella, o es la historia de vida un espacio al margen del poder? En: VILANOVA, Mercedes (ed.). El poder en la sociedad. Historia y fuente oral. Barcelona: Antoni Bosch editor, 1986, p. 196.

${ }^{8}$ SCHULTZ, Rainer. La historiografía sobre Cuba más allá de la isla (1993-2018). Temas. Jul./Dic. 2017, n. 91-92, pp. 13-20.

${ }_{9}$ LEWIS, Oscar; LEWIS, Ruth M. y RIGDON, Susan M. Viviendo la revolución: una historia oral de Cuba contemporánea: cuatro hombres. México: Joaquín Mortiz, 1980; LEWIS, Oscar, LEWIS; Ruth M. y RIGDON, Susan M. Cuatro mujeres. Vivencias durante la Revolución cubana. Madrid: Plaza \& Janés, 1980. A finales de los años noventa Marta Harnecker recogió el testimonio en forma de entrevistas de diecinueve mujeres y hombres cubanos del "Círculo de Abuelos de Santa Fe". HARNECKER, Marta. Pinceladas de la historia de Cuba (Testimonios de 19 abuelos). La Habana: Instituto Cubano del Libro; Editorial de Ciencias Sociales, 2003.

${ }_{10}$ DORE, Elizabeth. Historia oral y vida cotidiana en Cuba. Nueva sociedad. 2012, n. 242, pp. 36-55.

${ }^{11}$ BELL LARA, José [et al.]. Cuba: Periodo especial. La Habana: Editorial UH, 2017.
} 
de las mujeres en la insurrección cubana (1952-1958) ${ }^{12}$. En las últimas décadas, jóvenes historiadores cubanos han llevado a cabo un trabajo importante de rescatar la memoria regional, muchas veces a través de tesis de maestría o doctorado que, sin embargo, no llegan a publicarse y no logran trascender su proyección local.

La inserción de sus testimonios puede crear de forma fragmentaria las bases para una nueva comprensión de la historia socio-cultural del pasado inmediato, y en particular de la experiencia. Las historias de vida en toda su compleja diversidad nos permiten captar la realidad viva del pasado y de sus protagonistas, los hombres y mujeres en plural, insertos en el todo social y en relación dialéctica y permanente con él ${ }^{13}$. Sus relatos de "lo que ha sido" no son nunca reflejos exactos de la realidad sino más bien representaciones producto del proceso de rememoración que se produce en una entrevista de historia oral. Partimos de la asunción epistemológica de que memoria se gesta como una relación entre el presente y el pasado, entre la palabra dicha y sus omisiones o silencios, entre el individuo y la colectividad. Por tanto, como plantea Miren Llona, «a la historia le corresponde deconstruir o, si se prefiere, interrogar esos textos para poder hallar en ellos otros significados posibles más allá de sus significados preestablecidos o literales» ${ }^{14}$. El enfoque aquí adoptado es un proceso de acumulación o de encrucijada que guarda relación con la noción de intersubjetividad propuesta por Luisa Passerini, por cuanto «cada investigación y cada escritura son un proceso en marcha, un diálogo con otros, en varias partes del espacio y del tiempo ${ }^{15}$.

\section{Revolucionarios, internacionalistas y sobrevivientes}

La enorme aceleración del tiempo histórico y la superposición de acontecimientos hacen de los primeros años de la Revolución cubana un terreno particularmente complejo para el análisis. No es nuestro objeto el estudio en clave "desde arriba" de las dinámicas político-institucionales de la Revolución; materia por otra parte profusamente abordada en cuantiosas obras, sino que, tratamos de situar en el centro a determinados sujetos históricos y su experiencia vivida con la pretensión de acercarnos a la experiencia social de la Revolución cubana. Una revolución que, independientemente de las proyecciones que alcanzó en su tiempo, «fue una revolución latinoamericana». Lo que significa que es preciso analizarla a partir de su ubicuidad en procesos comunes a diversos países latinoamericanos, por

\footnotetext{
12 KRUIJT, Dirk. Cuba and the Revolutionary Latin American: An oral history. London: Zed Books, 2017; RAMÍREZ CHICHARRO, Manuel. Llamada a las armas. Las mujeres en la Revolución cubana 1952-1959. Madrid: Doce Calles, 2019.

13 FRASER, Ronald. La Historia oral como historia desde abajo. Ayer. 1993, n. 12, p. 91; THOMPSON, Paul. Historia, memoria y pasado reciente. Escuela de Historia. Universidad Nacional de Rosario. 2003/2004, n. 20, p. 22; GARCíA-NIETO, María del Carmen. Valor y potencia de la fuente oral. En: GARCÍA-NIETO María del Carmen; VÁZQUEZ DE PRAGA, María José y VILANOVA, Mercedes (eds.). Historia, fuente y archivo oral. Actas del Seminario "Diseño de proyectos de Historia Oral». Madrid: Ministerio de Cultura, 1990, pp. 41-69.

${ }^{14}$ LLONA, Miren. Historia, memoria y oralidad. En: LEONÉ, Santiago y MENDIOLA, Fernando (coords.). Voces e imágenes en la historia. Fuentes orales y visuales. Investigación histórica y renovación pedagógicas. Pamplona: Universidad de Navarra, 2007, p. 56.

${ }_{15}$ PASSERINI, Luisa. Memoria y utopía. La primacía de la intersubjetividad. Valencia: Publicacions Universitat de València, 2006, p. 26.
} 
una parte, y a partir de sus particularidades específicas, por otra ${ }^{16}$. ¿Cuál fue el significado de la Revolución para sus protagonistas? ¿En qué escenarios se politizaron? ¿Y, cómo evolucionó su conciencia política?

\subsection{Revolucionarios: «Que me pongan en la lista...»}

Las fuentes orales ponen en tela de juicio toda visión teleológica, esto es, cualquier tendencia a enfocar la investigación solo en términos de lo que logró imponerse. Ello nos recuerda las múltiples vías posibles, las aceleraciones de la historia, las contradicciones y ambigüedades de los procesos históricos, la contingencia y lo excepcional. Los acontecimientos son imprevisibles y pueden variar el ritmo de las estructuras y de la propia historia ${ }^{17}$. Lo cierto es que, en aquel enero de 1959, aun con el ejército batistiano derrotado, nada estaba escrito. El derrocamiento de la dictadura y el triunfo de la Revolución no fueron cosas idénticas. A los ojos de la gente que vivió aquellos años, el proceso estaba lleno de incertidumbres. Existen testimonios que alumbran aspectos difícilmente accesibles a través de las fuentes escritas. Estos constituyen una vía para aproximarnos a realidades tan inasibles como los miedos y esperanzas, en definitiva, a las emociones colectivas que genera un proceso histórico ${ }^{18}$. En este sentido, es extraordinariamente clarividente el testimonio de Carlos Menéndez, que vivió en La Habana el fin de la dictadura de Batista:

«Llegó el primero de enero y entonces todo cambió y empezamos a trabajar. Fue una alegría desbordante. La columna llegó el día 8 de enero, pero ya desde el día 1 la alegría era desbordante. Parecía que todo el mundo estaba borracho. Fue una efervescencia, un delirio.... Todo el mundo creía que todo se iba a arreglar, que todo iba a ser bueno, y todo no ha sido bueno. La vida es más dura. Pero en aquel momento, todo era un sueño. Sueño por haberse librado de ese ladrón, asesino; era un sádico. Allí empezó el trabajar, el enfrentamiento con Estados Unidos, las contradicciones, toda la historia que vino después, que todavía sigue. Pero bueno, fueron momentos muy bonitos. Los primeros años de los años sesenta, el Che Guevara... Fueron momentos de una gran ilusión, una gran felicidad. Trabajábamos felices, nos pasábamos la vida trabajando sin parar. Dormíamos arriba del buró y seguíamos trabajando " ${ }^{19}$.

En su relato podemos ver como el "yo social" emerge en toda su dimensión narrativa permitiendo comunicar su experiencia en términos de representaciones colectivas. Asimismo, atisbamos la vinculación entre lo pasado y lo futuro que dimensionan un espacio de la experiencia y un horizonte de expectativas. Al haberse realizado el proyecto político originado por la Revolución, se desgastan las viejas

\footnotetext{
${ }^{16}$ MIRES, Fernando. La rebelión permanente. Las revoluciones sociales en América Latina, Madrid: Siglo XXI, 2011, pp. 279-278 [1988].

17 TREBITSCH, Michel. El acontecimiento. Clave para el análisis del tiempo presente. Cuadernos de Historia Contemporánea. 1998, n. 20, pp. 29-40.

${ }^{18}$ La potencialidad de la historia oral para constituir un acercamiento a la "memoria emocional" es señalada por PLAMPER, Jan. Historias de las emociones: caminos y retos. Cuadernos de Historia Contemporánea. 2014, n. 6, p. 28.

${ }^{19}$ Entrevista de Óscar López Acón a Carlos Manuel Menéndez Lara (1936), La Habana, 3 de octubre de 2019. Diversos testimonios confluyen en señalar este acontecimiento como una auténtica «apoteosis», véase HARNECKER, Marta. Pincelas de la historia... Op. cit., p. 69 y p. 93.
} 
expectativas en las nuevas experiencias ${ }^{20}$. A menudo, representaciones sociales de fuerte contenido emocional tejen la identidad de varias generaciones acerca de lo vivido y le confieren un sentido. Tal y como postula William Reddy, las emociones nos ayudan a la hora de comprender fenómenos complejos relacionados con el cambio social ${ }^{21}$. Los años sesenta fueron los años de la «luna de miel» de la Revolución. Constituye un lugar común en los testimonios la idea de un verdadero "fervor revolucionario" hasta el paroxismo del "enamoramiento», como recoge Lewis $^{22}$. Podemos hablar de un auténtico "régimen de emotividad" de la Revolución determinado por grandes esperanzas puestas en dicho proceso.

Una nueva élite había podido movilizar masivamente a la sociedad en torno a un programa de reformas sociales e independencia nacional. Se abría así un horizonte para llevar a cabo la realización de muchos sueños e ideales. La Revolución debía implicar un cambio drástico en las estructuras, instituciones sociales y económicas que beneficiase a las mayorías nacionales. En la memoria colectiva de esta generación -que se reivindicaba como la «generación del centenario» de Martí, asumiendo así su herencia política- pervivía el recuerdo de la Revolución de 1933 que derrocó al régimen dictatorial de Gerardo Machado, como un intento frustrado de construir un Estado nacional cubano democrático. Los sucesivos gobiernos habían hecho de la Constitución de 1940 un cementerio de promesas incumplidas. El Movimiento 26 de Julio, partícipe de una cultura política trasnacional, era conocedor de las experiencias de los reformismos incompletos, como la revolución boliviana de 1952; la derrotada reforma moderada de Jacobo Arbénz en Guatemala en 1954; e incluso el reformismo de Perón y su giro derechista final, preludio de su derrota en 1955. Por ello, el cumplimiento de las reformas sociales llevaba en potencia el enfrentamiento con los intereses oligárquicos y del capital norteamericano. «La Revolución —dijo Fidel Castro- es nuestro gran maestro»; lo importante será empezar las cosas para demostrar el compromiso a través de la acción ${ }^{23}$.

Una visión desde dentro de la Revolución parece situar las coordenadas de la historia en el tremendo debate sobre la necesidad y profundidad de la reforma agraria, «punto de choque, elemento de fricción y de tensión entre el espectro de fuerzas que podían reclamarse como triunfadoras», según la tesis de Paco Ignacio Taibo II. El pulso de los acontecimientos en la prensa diaria, los guiones radiofónicos, los discursos de los cuadros, las movilizaciones sociales y la memoria de los testigos, así lo atestiguan. El año uno, sin duda, es el año del debate en torno a la revolución agraria prometida. Una reforma agraria que tenía que enfrentar la realidad de un país dominado por el latifundio, donde el 1,5 de los propietarios

\footnotetext{
${ }^{20}$ KOSELLECK, Reinhart. Futuro pasado: para una semántica de los tiempos históricos. Barcelona: Paidós, 1993, p. 356 [1979].

${ }^{21}$ REDDY, William M. The Navigation of Feeling: A Framework for the History of Emotions. New York: Cambridge University Press, 2001, p. 199.

${ }_{22}$ KRUIJT, Dirk. Cuba and the Revolutionary... Op. cit., pp. 64 y 70-71. LEWIS, Oscar; LEWIS, Ruth M. y RIGDON, Susan M. Viviendo la revolución... Op. cit., pp. 167-191.

${ }^{23}$ CANCINO, Hugo. El discurso ideológico de la Revolución cubana. Para un estudio de las raíces histórico-ideológicas de la revolución. Histórica: Debates e Tendências. Ene./Jun. 2010, vol. 10, n. 1, pp. 73-86. La frase de Fidel Castro, citada en LÓPEZ-ÁVALOS, Martín. La cultura política de la vanguardia o la construcción del ethos revolucionario. Cuba 1952-1959. TZINTZUN. Ene./Jun. 2011, n. 53 , p. 103.
} 
poseían el $46 \%$ de la tierra, donde dos terceras partes de los trabajadores agrícolas eran jornaleros sin tierra, trabajadores de los ingenios azucareros, peones 0 subarrendatarios $^{24}$. Durante la contienda, en las zonas liberadas por el Ejército Rebelde, las organizaciones campesinas se habían movilizado para apoyar la ley № 3 de la Sierra Maestra, firmada el 3 de octubre de 1958. Con el triunfo de la Revolución se desarrolló de inmediato un movimiento asamblearista campesino por todo el país. Se reorganizaron y fortalecieron las viejas asociaciones campesinas y se crearon otras nuevas donde antes no existían para movilizarse en apoyo de la ley de Reforma Agraria, que fue aprobada el 17 de mayo de $1959^{25}$.

«La Reforma agraria es el Rubicón. Ya los yanquis habían decidido que Fidel no podía ser antes de que triunfara. Apoyaron a Batista, manejaron con los militares, hicieron un intento de golpe de Estado... Pero, lo cierto es que, ya cuando se firma la ley de la Reforma Agraria, que incluso fue una lucha dentro de una Revolución, porque la Revolución tenía ministros que eran gente no avanzada... ¿Y, qué cosa es la ley de Reforma Agraria? Darle la tierra a los campesinos» ${ }^{26}$. Para Ernesto Guevara la experiencia del campesinado fue el elemento decisivo en la conformación de la conciencia revolucionaria. En Pasajes de la guerra revolucionaria escribió «nunca han sospechado aquellos sufridos y leales pobladores de la Sierra Maestra el papel que desempeñaron como forjadores de nuestra ideología revolucionaria». En la Sierra se empezó «a hacerse carne en nosotros la conciencia de la necesidad de un cambio definitivo en la vida del pueblo. La idea de la reforma agraria se hizo nítida y la comunión con el pueblo dejó de ser teoría para convertirse en parte definitiva de nuestro ser ${ }^{27}$.

En una mañana de septiembre de 1959, el por entonces Coordinador Provincial del Movimiento 26 de Julio, Ángel Fernández Vila, fue convocado por Fidel Castro a una reunión en el Instituto de Reforma Agraria (INRA). En esa «reunión inolvidable», como el mismo nos relata, Fidel Castro le propuso sumarse trabajar en el INRA. En su despacho le mostró un gran plano de la península de Zapata, un inhóspito territorio presidido por una extensa ciénaga. «Fidel había estado pensando en el porvenir de los humildes leñadores y carboneros que, durante muchos años, habían vivido en el pantano excluidos y explotados salvajemente por los terratenientes que se habían apropiado, ilegalmente de las tierras de esa península». En aquel vasto territorio se habían planteado dos proyectos: el primero, propuesto por los asesores soviéticos, consistía en aprovechar la importante reserva energética que constituía la enorme extensión de suelo de turba, combustible de alto contenido energético, para poner a funcionar una central termoeléctrica que abasteciera de electricidad a toda la zona central del país. El otro proyecto, consistía en construir "polders", hacer diques y canales como en Holanda, para desecar el pantano y desarrolla una agricultura de alto nivel:

\footnotetext{
${ }^{24}$ TAIBO II, Paco Ignacio. Ernesto Guevara, también conocido como el Che. Barcelona: Crítica, 2017, p. 362 y p. $372-375[1996]$.

${ }^{25}$ REGALADO, Antero. Las luchas campesinas en Cuba. La Habana: Editorial Orbe, 1976, pp.167169.

26 Entrevista de Óscar López Acón a Víctor Manuel González Alvear (1940), La Habana, 18 de septiembre de 2019.

${ }_{27}$ GUEVARA, Ernesto Che. Pasajes de la Guerra Revolucionaria. Tafalla: Txalaparta, 1997, p. 83 у р. 154 [1963].
} 
«La primera variante del proyecto resolvía el problema de la falta de energía eléctrica. Pero ¿qué les dejaría a los humildes y explotados pobladores de la ciénaga, sino un enorme hueco resultante de la extracción? El proyecto de desecación de la ciénaga, aunque costoso y de no inmediatos resultados económicos ayudaría a resolver la terrible situación social en que habían vivido los pobladores. No importaba que en lugar de los resultados económicos inmediatos, por el contrario, se tuvieran que hacen cuantiosas inversiones y trabajar durante años en este proyecto. Con él se lograría, al final, cambiar las condiciones de vida y trabajo de los leñadores y carboneros, al incorporarlos a una actividad económica superior, más humana y gratificante, para ellos y para sus humildes familias... Fidel le daba prioridad al proyecto que conduciría a la solución de la terrible situación social de los pobladores de la ciénaga y comprendí entonces qué cosa era la Revolución, y cuán extraordinario era aquel hombre» ${ }^{28}$.

«Ahí me volví revolucionario. Yo no era revolucionario cuando estuve en la guerrilla, era insurreccionalista. Después de esa conversación yo entendí lo que teníamos que hacer», explica Ángel Fernández Vila ${ }^{29}$.

Cabe interrogarnos acerca de cómo uno de los países de América Latina donde Estados Unidos tenía mayor influencia cultural, política e ideológica, transitó hacia un cambio tan profundo en tan solo tres años, entre 1959 y 1961. Un país en el que, citando las palabras de Arnaldo Silva —combatiente clandestino integrante del Movimiento 26 de Julio (M-26-7) —, la población era «mayoritariamente anticomunista por la ignorancia, por prejuicio a la Unión Soviética» ${ }^{30}$, debido a la influencia del macartismo de los años cincuenta en el contexto de la Guerra Fría. Y lo que es más, ni siquiera importantes cuadros del M-26-7 tenían una formación y una conciencia política comunista. Huberman y Sweezy señalan que «esta es la primera vez en cualquier ocasión o lugar que una Revolución genuinamente socialista se ha hecho ¡por no comunistas! ${ }^{31}$. ¿Cuál fue exactamente «la obra de la Revolución»? Pasemos a escuchar directamente el testimonio de Arnaldo Silva:

«La Revolución de manera inmediata no escatimó esfuerzo alguno en aumentar el empleo, elevar el nivel de vida, rebajando por aquí y por allá, dando trabajo al que no lo tenía, construyendo escuelas, la salud pública gratuita. El pueblo sintió de manera inmediata los grandes beneficios del socialismo. En un principio no se decía, hasta que vino Girón, y Fidel aprovechó para decir: estamos construyendo el socialismo, en abril de 1961. Había una obra que respaldaba todo eso. ¿Quiénes eran los buenos? los americanos ¿Y, los malos? los soviéticos. Pero, resulta que los buenos nos quieren matar, nos agreden, nos bloquean. Los soviéticos nos compran el azúcar, nos dan el petróleo, nos arman. Entonces no son tan malos (...) Eso fue despejando el camino, haciendo que disminuyera progresivamente el prejuicio a la Unión Soviética. A estos factores se une otro no menos importe: Es la personalidad de Fidel Castro. La fe extraordinaria en Fidel.

\footnotetext{
${ }^{28}$ Entrevista de Óscar López Acón a Ángel Fernández Vila (1932), La Habana, 19 de octubre de 2019. Recogido en: Una entrevista inolvidable. En: FERNÁNDEZ VILA, Ángel. Por las ideas del Moncada. Relatos. La Habana: Verde Olivo, 2013.

${ }^{29}$ Entrevista de Óscar López Acón a Ángel Fernández Vila (1932), La Habana, 19 de octubre de 2019.

${ }^{30}$ Entrevista de Óscar López Acón a Arnaldo Silva León (1938), La Habana, 2 de octubre de 2019.

31 HUBERMAN, Leo y SWEEZY, Paul M. Cuba. Anatomía de una Revolución. Buenos Aires; Montevideo: Palestra, 1961, p. 194.
} 
El carisma extraordinario de Fidel. Si algún hombre ha desempañado en la historia un papel relevante en cambiar un pueblo, en transformarlo, ese fue Fidel Castro en Cuba. Hasta el punto de una fe tan grande, que aquí había una consigna que el pueblo gritaba: Si Fidel es comunista que me pongan en la lista. Demostraba la confianza tan grande que había en un hombre» ${ }^{32}$.

A todas luces el testimonio nos muestra el enorme poder carismático de la figura de Fidel Castro, hasta el punto de considerarlo un factor explicativo más del proceso histórico. Uno de carácter excepcional, como el mismo Ernesto Che Guevara reconoció en su célebre artículo Cuba: ¿Excepción histórica o vanguardia en la lucha anticolonialista $^{33}$. La base de popularidad de Fidel Castro era indudablemente su relación única con el pueblo, ya fuera en la pantalla de la televisión o en los discursos públicos. Su ampulosa retórica propia de los políticos de otra época y herencia de tradiciones radicales cubanas conectaba con la multitud y establecía una suerte de diálogo con ella. Se trataba de un «liderazgo dialógico», en palabras del pedagogo marxista Paolo Freire, pues basaba su legitimidad en la interpelación directa de las masas, a las que hablaba de sus aciertos, errores, de sus equívocos y de sus dificultades, de la imposibilidad inmediata de una forma de acción o su inadecuación al movimiento ${ }^{34}$.

K. S. Karol señala que los jóvenes sabían muy poco sobre socialismo y comunismo; esas dos palabras, «al haber sido presentadas durante tanto tiempo como sinónimos del infierno por los mass media, aún les asustaban»; pero, sin embargo, consideraban un ultraje el estado en el que se encontraban sumidos los campesinos pobres de todo el país y su adhesión a Fidel era ilimitada. «Soy una revolucionaria», «si Fidel ha dicho que nuestra revolución es socialista, lo sabe mejor que yo. Y si él es socialista, yo también», señalaba Julia, una joven alfabetizadora 17 años de Santa María del Rosario ${ }^{35}$. Ángel Fernández Vila, a la sazón Coordinador del Movimiento 26 de Julio en la Provincia de La Habana, argumenta que «el pueblo nuestro era anticomunista por el macartismo en América. Nosotros éramos anticomunistas; no sabíamos que era el comunismo (...). Ninguno de nosotros había leído esos teóricos marxistas. El único que había leído un poquito era Fidel y el Che que veía ya preparado» ${ }^{36}$.

El factor fundamental que debe plantearse se refiere a los mecanismos de la experiencia vivida de la Revolución. En la forma en que aquellos hombres y mujeres tomaron parte en las movilizaciones, las reformas sociales, el trabajo, los debates, y, paralelamente, articularon un sentido colectivo de agravio, amenaza, agresión, y sobre todo, esperanza puesta en el futuro, se conformaron como el sujeto colectivo revolucionario. Así, las organizaciones de masas y la experiencia de millones de cubanos activos en ellas reemplazaron el papel potencial de socialización del partido dirigente. En su seno, la ideología inculcada fue, como era de esperar, «el

\footnotetext{
32 Entrevista de Óscar López Acón a Arnaldo Silva León (1938), La Habana, 2 de octubre de 2019.

${ }^{33}$ GUEVARA, Ernesto Che. Cuba: ¿Excepción histórica o vanguardia... Op. cit., p. 126.

34 BALFOUR, Sebastian. Fidel Castro. Una biografía política. Barcelona: Península, 2009, pp. 115117; FREIRE, Paulo. Pedagogía del oprimido. Madrid: Siglo XXI, 2019, pp. 128-130 y p. 168 [1970].

${ }^{35}$ KAROL, K. S. Los guerrilleros en el poder. Barcelona: Seix Barral, 1972, pp. 60-61.

${ }^{36}$ Entrevista de Óscar López Acón a Ángel Fernández Vila (1932), La Habana, 19 de octubre de 2019.
} 
cubanismo". Ello se debió a que estaban dirigidas por personas que participaron en la lucha insurreccional y clandestina de 1953-1958 o en el trabajo colectivo y la defensa de 1959-1962; lo que les legitimaba tanto a ellos como al marco ideológico nacionalista en el que se desarrollaron. La combinación decisiva de «radicalización empírica» y «apelación a la tradición cubana» reforzó a esta última, como plantea Antoni Kapcia. Asimismo, se agregaron nuevos elementos que reforzaron el núcleo central de esta ideología, como por ejemplo su agrarismo ${ }^{37}$. De igual modo, la experiencia de la "amenaza extranjera" y el "asedio"; «el rostro oculto de todas las revoluciones» - del que fuera testigo Sartre, aquel 4 de marzo de 1960 con la explosión de La Coubre ${ }^{38}$-, fortalecieron el sentimiento nacionalista.

Los Comités de Defensa de la Revolución (CDR), el Ejército Rebelde, las Milicias Nacionales Revolucionarias (MNR), los seminarios y asambleas ligadas a la reforma agraria, o el Instituto Nacional de Reforma Agraria (INRA), -que representó el trabajo de la Revolución en el campo-, fortalecieron el nuevo radicalismo. En medio de aquella polarización doméstica e internacional se multiplicó la creativa política de masas de la Revolución. Cientos de miles de jóvenes voluntarios que cursaban la secundaria y el bachillerato acometieron en el curso de 1961 una formidable Campaña de Alfabetización. En un año, 300.000 alfabetizadores cubanos enseñaron a leer y escribir a 707.000 campesinos, la mayoría oriundos de regiones montañosas del centro y el oriente de la isla, desde el Escambray a la Sierra Maestra $^{39}$.

Ángel Jiménez González era cantinero cuando triunfó la Revolución. Fue elegido responsable de la milicia del sindicato por sus compañeros. Entonces la Milicia Nacional Revolucionaria se organizaba por sectores. «Me mandaron a la Sierra Maestra a subir tres veces el Turquino como prueba de resistencia física y después a Matanzas a un curso que debía durar tres meses». Pero el 15 de abril, a una semana de graduarse, se produjo el bombardeo sorpresivo de los aeródromos de Ciudad Libertad, San Antonio de los Baños y del aeropuerto José Antonio Maceo, de Santiago de Cuba, que anunciaba la inminente invasión. «Un muchacho herido de muerte [Eduardo García Delgado], con su sangre, escribió en una pared Fidel; en una puerta. En el último estertor de la muerte, con sus últimas fuerzas puso en la pared Fidel, como una confesión de entrega» ${ }^{40}$. Nicolás Guillén inmortalizó con sus

\footnotetext{
${ }^{37} \mathrm{KAPCIA}$, Antoni. Ideology and the Cuban Revolution: Myth, Icon and Identity. En: FOWLER, William (ed.). Ideologues and ideologies in Latin America. Greenwood: Westport, 1997, p. 87. «No es la doctrina, sino la empiria, está volviendo socialista a Cuba»; HOBSBAWM, Eric. Los horizontes de Cuba. En: HOBSBAWM, Eric. jViva la Revolución! Sobre América Latina. Edición y compilación de L. Bethell. Barcelona: Crítica, 2018, pp. 37-41; KRUIJT, Dirk. Cuba and the Revolutionary... Op. cit., p. 63; KAROL, K. S. Los guerrilleros... Op. cit.

38 GONZÁLEZ AROCHA, Jorge. Sartre y el mundo encantado de la libertad. En: GÓMEZ VELÁZQUEZ, Natasha y VILÁ BLANCO, Dolores. Pensar Cuba hoy: forzando los bordes. La Habana: Editorial UH, 2018, p. 81.

${ }^{39}$ ROJAS GUTIÉRREZ, Rafael. Historia mínima de la Revolución cubana. Madrid: Turner, 2015, pp. 121-124. Uno de esos jóvenes, el maestro de dieciocho años Conrado Benítez, fue asesinado en enero de 1961 por una banda de alzados contrarrevolucionarios en el Escambray, causando una enorme indignación popular. RODRíGUEZ CRUZ, Juan Carlos. Hombres del Escambray. Los secretos de la victoria. La Habana: Capitán San Luis, 2015, p. 37.

40 Entrevista de Óscar López Acón a Ángel Jiménez González (1938), La Habana, 8 de octubre de 2019.
} 
versos este crudo episodio en el poema "La sangre numerosa" ${ }^{\prime 1}$.

Al día siguiente, en el sepelio de las víctimas celebrado en el cementerio de Colón, en La Habana, y ante una inmensa concentración de milicianos armados en estado de alerta preludio de la agresión, Fidel Castro proclamó el carácter socialista de la Revolución cubana: «eso es lo que no pueden perdonarnos: que estemos aquí, en sus narices, iy que hayamos hecho una revolución socialista en las mismas narices de los Estados Unidos! (...) Compañeros obreros y campesinos, ésta es la revolución socialista y democrática de los humildes, con los humildes y para los humildes. Y por esta revolución de los humildes, y por los humildes y para los humildes, estamos dispuestos a dar la vida» ${ }^{42}$. Todo el país movilizado ocupó sus puestos de combate, ya fuera para continuar la producción o la defensa. En la madrugada del día 17 desembarcaron en Bahía de Cochinos las primeras columnas de invasión de la denominada "Operación Pluto", resueltas a poner fin al proceso revolucionario. El peso del combate recayó en bisoñas unidades de milicias recién constituidas. Ángel Jiménez, que integraba una de ellas, fue enviado hacia Girón:

«Entramos por el central Australia, Pálpite, ahí había paracaidistas, combatimos y los liquidamos rápido. Y seguimos por la carretera de la Laguna de Zapata que va a Playa Larga. Era un terraplén más que una carretera (...). Como habíamos derrotado a los paracaidistas tan fácilmente no tuvimos en cuenta que la aviación era de ellos; entonces vimos un avión, un B-26 igual que los nuestros, con las mismas insignias nuestras. Después nos dimos cuenta que tenía unas bandas azules que lo identificaban y en ese momento no lo sabíamos y los saludamos llenos de entusiasmo. Cuando dio la vuelta la escuela [de milicias] tuvo veintidós muertos, entre eso y otros ataques. Ahí seguimos hasta que en la madrugada desalojamos a los que defendían Playa Larga».

A Ángel Fernández Vila el curso de los acontecimientos le sorprendió siendo delegado del INRA en la región de ciénaga de Zapata, cuando se encontraba con una veintena de carboneros en las afueras del poblado de Cayo Ramona, a unos ocho kilómetros de la invasión mercenaria. "Me cercaron con doce hombres. Ellos venían con carros artillados, morteros, cañones sin retroceso y nosotros con fusiles; nos fuimos echando para atrás, nos tiramos para la ciénaga, si no nos mataban; luego avanzamos para allá cuando se movilizaron todas las tropas » ${ }^{43}$. Fernández Vila asumió la dirección de la ofensiva en el sector de Pálpite-Playa Larga. Tras casi 72 horas de combate, la brigada mercenaria era desalojada de sus posiciones y se batía en retirada; el 19 de abril a las cinco y media, una columna blindada bajo la

\footnotetext{
${ }^{41}$ "Cuando con sangre escribe/ FIDEL este soldado que por la patria muere, / no digáis miserere: / esa sangre es el símbolo de la patria que vive, / Cuando su voz en pena,/ lengua para expresarse parece que no halla,/ no digáis que se calla,/ pues en la pura lengua de la Patria suena./ Cuando su cuerpo baja/ exánime a la tierra que lo cubre ambiciosa,/ no digáis que reposa, / pues por la Patria en pie resplandece y trabaja./ Ya nadie habrá que pueda/ Parar su corazón unido y repartido./ No digáis que se ha ido: / Su sangre numerosa junto a la patria queda». CANTÓN NAVARRO, José y SILVA LEÓN, Arnaldo. Historia de Cuba 1959-1999. Liberación Nacional y socialismo. La Habana: Editorial Pueblo y Nación, 2018 [, pp. 55-56 [2009].

${ }^{42}$ LÖWY, Michael. El marxismo en América Latina. Santiago de Chile: LOM Ediciones, 2007, pp. 279280.

${ }^{43}$ Entrevista de Óscar López Acón a Ángel Fernández Vila (1932), La Habana, 19 de octubre de 2019.
} 
dirección de Fidel Castro entraba en playa Girón sin encontrar resistencia ${ }^{44}$.

Después de Girón la agresión norteamericana continuó en forma de la "Operación Mangosta". Tan solo quince días después del fracaso de Bahía de Cochinos, el 4 de mayo de 1961, las altas esferas gubernamentales estadounidenses preparaban el documento "Cuba y el comunismo en el Hemisferio", donde planteaban la necesidad ineludible de liquidar la joven revolución porque «ha aportado un ejemplo de trabajo de un Estado comunista en las Américas, desafiando exitosamente a Estados Unidos». Así, al aislamiento diplomático y al bloqueo económico, se uniría en los meses y años sucesivos un ambicioso programa de "guerra sucia" lanzado por la CIA. Durante todo el año 1962 se intensificaron las actividades de terrorismo, asesinato, sabotaje, quema de cañaverales, ataques piratas e infiltraciones de grupos armados. De enero a agosto los actos de esa índole alcanzaron la cifra de 5.780; de los cuales 716 consistieron en sabotaje de centros económicos y sociales. Solo en la Sierra de Escambray las bandas armadas crecieron de 42 a 79 en septiembre. A pesar de esta escalada, quedó claro que la Revolución no caería sin una intervención militar directa. La crisis de octubre de 1962 obligó a Estados Unidos a una actuación más prudente. La lucha contra las bandas armadas en la Sierra de Escambray continuó hasta marzo de $1965^{45}$.

La joven Revolución transitó sus primeros años en una atmósfera de campo de batalla. El país independiente, en palabras de Fanon, «tenazmente transita en una especie de locura creadora, se lanza a un esfuerzo gigantesco y desproporcionado" para crear las bases materiales de la modernización y el desarrollo ${ }^{46}$. Ernesto Guevara quería hacer permanente el «espíritu de Octubre», la movilización política y el desarrollo ininterrumpido de la revolución. La movilización de la sociedad, y muy especialmente de los jóvenes, por medio de todas las organizaciones de masas, constituyó el elemento característico. Silvio Rodríguez, célebre representante del movimiento musical de la nueva trova, era uno de esos jóvenes:

«En nuestro país hay cierta cantidad de gente que al triunfo de la Revolución tenía entre diez y quince años. A estos les tocó alfabetizar, hacerse milicianos aún muy jóvenes, pelear o esperar pelear en Girón, en el Escambray o defendiendo nuestras costas. Son gente que tenía entre catorce y diecinueve años cuando Kennedy nos amenazó con la atómica. Por aquellos días hacían guardias con fusiles, como todo nuestro pueblo. A esos muchachos les tocó hacerse artilleros, manejar nuestros primeros cohetes antiaéreos, sembrar café, sumarse a la Columna Juvenil del Centenario o a la Columna Juvenil del Mar. Durante toda la década del setenta cortaron caña como locos, pero sobre todo en la histórica zafra del setenta» ${ }^{47}$.

\footnotetext{
${ }^{44}$ PINO MACHADO, Quintín. La batalla de Girón. Razones de una victoria. La Habana: Editorial de Ciencias Sociales, 1983, pp. 108-109 y pp. 172-175.

${ }^{45}$ DÍEZ ACOSTA, Tomás. La guerra sucia contra Cuba. Documentos del gobierno de EE.UU. sobre la Operación Mangosta. Tomo 1. La Habana: Editora Política, 2018, pp. 7-15 y pp. 20-37; SUÁREZ AMADOR, José. En los umbrales de la Revolución. Terrorismo y bandidismo en Occidente (19591965). La Habana: Editorial Ciencias Sociales, 2018; RODRíGUEZ CRUZ, Juan Carlos. Hombres del Escambray... Op. cit.

${ }^{46}$ FANON, Frantz. Los condenados de la tierra. Tafalla: Txalaparta, 2018, p. 74 [1961].

47 CASAUS, Víctor y ROGELIO NOGUERAS, Luis. Silvio: Que levante la mano la guitarra. La Habana: Centro Cultural Pablo de la Torriente Brau, 2017, p. 216.
} 
Para el ideario guevarista, hegemónico durante la década de los sesenta entre los líderes de la Revolución, el trabajo voluntario era importante no solo desde el punto de vista económico — habida cuenta de la importancia de dicho trabajo para asegurar la zafra azucarera-, sino también y sobre todo como factor que desarrollaba la conciencia de los trabajadores, «en tanto que escuela práctica y cotidiana de autoeducación política» ${ }^{48}$. El ethos guerrillero imprimió en la sociedad cubana un carácter "militarizado", de cariz popular, que nada tenía que ver con la visión conservadora del término, a decir de Kapcia. La movilizaciones de los cubanos por el trabajo, la producción, la defensa o la educación en "brigadas", "campañas", "columnas", "ofensivas" ayudaron a reforzar el poder de movilización de ese discurso, porque incluso construyendo una escuela, aprendiendo a leer 0 sembrando caña de azúcar, no solo se estaba defendiendo a la Revolución, sino que se formaba parte de una sempiterna tradición patriótica que se remontaba al "Grito de Yara" de 1868, que diera inicio a la Guerra de los Diez Años ${ }^{49}$.

Víctor Manuel González Albear, miembro de la lucha clandestina y luego Secretario Regional del Partido Comunista de Cuba en la Provincia de Holguín, explica que los jóvenes concurrieron espontánea y masivamente a alistarse al servicio militar cuando se promulgó la ley de conscripción obligatoria -el 26 de noviembre de $1963{ }^{50}$. Recuerda que estaban muy presentes los «valores de heroísmo» y «la idea de sacrificio del Ejército Rebelde». «Los jóvenes se entrenaban, subían las montañas, querían hacer algo para emular lo que hicieron los combatientes revolucionarios» ${ }^{51}$. Este ethos se armonizaba con la visión normativa oficial de una «masculinidad revolucionaria»; una juventud «de carácter firme» «forjada sobre el sacrificio» como postulaba en 1965 el Comandante Raúl Castro, por entonces Ministro de las Fuerzas Armadas Revolucionarias ${ }^{52}$.

\subsection{Internacionalistas: « ¿ Vas para Angola?»}

Desde 1961 armas y combatientes cubanos habían comenzado a llegar a varios países de América Latina y África en apoyo de la lucha anticolonial ${ }^{53}$. El 11 de diciembre de 1964, en su discurso en las Naciones Unidas, Ernesto Guevara había exhortado a las naciones libres a aprestarse a «vengar el crimen del Congo», perpetrado por los imperialistas norteamericanos y belgas con el asesinato de Patricio Lumumba. «La filosofía del despojo no ha cesado, sino que se mantiene

\footnotetext{
${ }^{48}$ LÖWY, Michael. El pensamiento del Che Guevara. Madrid: Siglo XXI, 2007, pp. 75-79 [1970].

${ }^{49}$ KAPCIA, Antoni. Cuba in Revolution. A history since the fifties. London: Reaktion Books, $2008, \mathrm{p}$. 101.

50 Entrevista de Óscar López Acón a Víctor Manuel González Albear (1940), La Habana, 18 de octubre de 2019. Ley 1129 del 26 de noviembre de 1963 del Servicio Militar Obligatorio (SMO). En: Leyes del gobierno revolucionario de Cuba: Folletos de divulgación legislativa. 1963, n. 50. «Desde las primeras horas el pueblo se agolpa junto a los locales de inscripción. Largas filas frente a la puerta de cada centro. La ciudadanía responde al llamado de la patria». La veracidad del testimonio de González Albear se constata al consultar el editorial de RODRÍGUEZ, Javier. Entusiasmo popular en la inscripción para el servicio militar. Bohemia. 1963, (6 Diciembre), pp. 68-70.

51 Entrevista de Óscar López Acón a Víctor Manuel González Alvear (1940), La Habana, 18 de septiembre de 2019.

52 SIERRA MADERO, Abel. El trabajo os hará hombres: Masculinización nacional, trabajo forzado y control social en Cuba durante los años sesenta. Cuban Studies. 2016, n. 44, p. 316.

53 ZANETTI, Óscar. Historia mínima de Cuba. Madrid: Turner, 2013, p. 285.
} 
más fuerte que nunca (...) nuestros ojos libres se abren hoy a nuevos horizontes y son capaces de ver lo que ayer nuestra condición de esclavos coloniales nos impedía observar; que la civilización occidental esconde bajo su vistosa fachada un cuadro de hienas y chacales $" 54$. Desde abril hasta noviembre de 1965 el Che dirigió un contingente cubano a orillas del lago Tanganica en el Congo, para apoyar a la guerrilla de Laurent Kabila. En enero de 1966 La Habana acogió la primera Conferencia Tricontinental que consolidó a Cuba como la vanguardia revolucionaria del Tercer Mundo. El compromiso cubano en África en la década del setenta fue una continuación de estos proyectos.

A mediados de octubre de 1975 columnas blindadas sudafricanas atravesaron la frontera sur de Angola y avanzaron rápidamente al interior del territorio mientras tropas mercenarias zairenses amenazaban por el norte con objeto de ocupar el país antes del 11 de noviembre, fecha en que estaba prevista la proclamación de la independencia. Washington, principal aliado del régimen del apartheid de Sudáfrica, buscaba «aplastar los legítimos intereses del pueblo angolano e implantar un gobierno títere»; «frustrar la independencia de Angola y convertirla prácticamente en su condominio junto con el corrupto Mobutu, dueño de Zaire», en palabras de Fidel Castro $^{55}$. Entonces, el presidente Agostino Neto solicitó la ayuda militar cubana. De inmediato, tropas especiales del Ministerio de Interior y unidades regulares de las FAR fueron trasladas por mar y aire, que se sumaron a los quinientos instructores militares cubanos que ya estaban colaborando con las fuerzas angolanas. Se inició así lo que se llamó la "Operación Carlota», en honor a una mujer negra esclava que había encabezado un levantamiento de esclavos en Matanzas en 1843.

Entre noviembre de 1975 y marzo de 1975, 30.000 soldados cubanos derrotaron a las fuerzas invasoras salvaguardando la independencia de Angola de su caída en manos de la coalición de fuerzas neocoloniales, esto es, las fuerzas armadas sudafricanas del apartheid, por el sur, y sus clientes, las fuerzas insurgentes de la UNITA —dirigidas por Jonás Savimbi y armadas por la CIA—, por el noreste; y las del FNLA por el norte, lideradas por Holden Roberto, que contaba con el apoyo del dictador congoleño Mobutu ${ }^{56}$. Justo Gimeno fue uno de esos internacionalistas cubanos que tomaron parte en la decisiva intervención:

«Primero nos tiramos en Cabo Verde, luego fuimos a Luanda. Desde ahí nos repartíamos a las operaciones donde cada uno iba. El 9 de octubre [de 1975] empezamos los combates. Nosotros recuperamos la provincia de Luso [Luena], una de las más importantes, y de ahí subimos al norte, hacia la frontera con Zaire (...). Estuve en el primer contingente; luego vino la lucha contra la UNITA, que pasaba a la lucha guerrillera como decía un documento que se ocupó en el asalto a una de sus bases, eso fue la segunda etapa».

\footnotetext{
54 GUEVARA, Ernesto Che. En las Naciones Unidas (11 de diciembre de 1964). En: GUEVARA, Ernesto Che. Solidaridad e internacionalismo. La Habana: Editorial de Ciencias sociales, 2018, pp. 43-71, p. 50 y p. 52.

${ }^{55}$ RAMONET, Ignacio. Fidel Castro. Biografía a dos voces. Barcelona: Debate, 2016, pp. 327-336 [2004].

${ }_{56}$ GLEIJESES, Piero. Conflicting Missions: Havana, Washington and Africa, 1959-1976. Chapel Hill: University of North Carolina Press, 2001, p. 380.
} 
En 1983 Justo Gimeno volvió a la antigua colonia portuguesa para instruir al contingente angolano en la lucha contra las guerrillas de la UNITA, labor que le granjearía el ascenso a teniente coronel; «entrenábamos primero con batallones, luego creamos brigadas de angolanos y cubanos. Ahí se luchó bastante» 57 .

El fenómeno del internacionalismo cubano adquirió una dimensión de masas a mediados de los setenta ${ }^{58}$. Era la expresión más auténtica, más pura, más universal, más combativa y más concreta del «humanismo revolucionario» ${ }^{59}$. La generación llamada a educarse en el espíritu revolucionario del Che bajo las consignas de «Estudio, Trabajo y Defensa» ${ }^{60}$, fue la que nutrió sus filas. Como nos relata Ángel Jiménez, veterano de dos campañas internacionalistas, «jugó un papel tremendo el Che, la personalidad del Che en África y en Bolivia crearon una atmósfera en la juventud cubana que, al que le decían "vas para Angola" y decía que no, era un "rajao", y rajao era una mala palabra, socialmente estaba muy mal visto» ${ }^{61}$.

La ayuda cubana no se circunscribió únicamente al terreno militar. El noventa por ciento de los portugueses que vivían en Angola en abril de 1974 se habían ido, llevándose casi todo lo que hacía que el sistema de gobierno y la economía funcionase $^{62}$. Antonio Díaz Ruiz, que desempeñaba la Dirección del Departamento de Educación Interna del Comité Central del Partido Comunista de Cuba (PCC), fue enviado por la Secretaría del Partido para organizar el sistema político angolano el 24 de diciembre de 1976. Se trataba de una petición expresa que Agostino Neto le había hecho a Fidel Castro.

«Cuando yo llegó allí me recibe a los pocos días el segundo jefe del MPLA, que era Lucio Lara. Me dio una orientación de lo que ellos querían que yo hiciera. Que colaborara en organizar en Angola todo el sistema de trabajo político e ideológico (...) entonces, empezamos a viajar por toda Angola. En Cabinda estuvimos dos meses; allí había una situación difícil, con un movimiento contrarrevolucionario muy fuerte. De ahí visitamos todas las provincias. Yo estuve un año entero, creando las escuelas con los militantes y los cuatros del MPLA; a su vez, estábamos nosotros allí y seguía la guerra. El norte ya se había liberado, pero en el centro y el este estaba la UNITA y los sudafricanos (...). Creamos escuelas del partido, de las organizaciones de masas; el sistema político organizado para las masas y los trabajadores en general. Y, sobre todo, en primer lugar, trabajamos por la alfabetización. Entonces casi toda la población era analfabeta» ${ }^{63}$.

El país se quedó sin personal cualificado, incluido el personal sanitario. Los médicos comenzaron a llegar a Angola finales de noviembre de 1975, mientras los sudafricanos todavía trataban de romper las defensas cubanas. En los años

\footnotetext{
${ }^{57}$ Entrevista de Óscar López Acón a Justo Gimeno (1939), La Habana, 7 de octubre de 2019.

${ }^{58}$ Casi 337.000 soldados cubanos sirvieron en Angola entre 1975 y 1991 . Del total de 2.425 cubanos internacionalistas que perdieron la vida, 2.103 lo hicieron en este país. GLEIJESES, Piero. Visions of Freedom: Havana, Washington, Pretoria, and the Struggle for Southern Africa, 1976-1991. Chapel Hill: University of North Carolina Press, 2013, p. 521.

${ }^{59}$ LÖWY, Michael. El pensamiento del Che... Op. cit., p.121.

60 M. G. C. Me quiero inscribir ¡Ya! en el SMO. Bohemia. 1963, (29 Noviembre), pp. 18-19.

${ }^{61}$ Entrevista de Óscar López Acón a Ángel Jiménez González (1938), La Habana, 8 de octubre de 2019.

62 GLEIJESES, Piero. Conflicting Missions... Op. cit., pp. 381-382.

${ }^{63}$ Entrevista de Óscar López Acón a Antonio Díaz Ruiz (1930), La Habana, 7 de octubre de 2019.
} 
sucesivos, miles de médicos, profesores y técnicos cubanos prestaron ayuda en sus diferentes campos en este país, pero también en países como Etiopía, GuineaBissau, Ghana, Uganda, o Gambia, entre otros. De acuerdo a las estadísticas del Ministerio de Relaciones Exteriores cubano (MINREX), entre 1959 y 2001, alrededor de 81.000 internacionalistas civiles trabajaron en África, 47.000 en América Latina y 10.000 lo hicieron en Oriente Medio. Se trata, en palabras de Dirk Kruijt de la más altruista contribución del internacionalismo cubano ${ }^{64}$.

La victoria de Angola en 1976 dio a los cubanos una enorme gratificación, tanto más significativa por cuanto resarcía el sentimiento nacional tras una serie de reveses acumulados. Como observó García Márquez «desde la victoria de Girón, hacía más de quince años, habían tenido que asimilar con los dientes apretados el asesinato del Che Guevara en Bolivia y el del presidente Salvador Allende en medio de la catástrofe de Chile, y habían padecido el exterminio de las guerrillas en América Latina y la noche interminable del bloqueo, y la polilla recóndita e implacable de tantos errores internos del pasado " ${ }^{65}$. Sin embargo, la intervención en Angola rebasó con creces sus efectos inmediatos; pues cambió la forma en que la sociedad cubana abordó su historia nacional, su identidad, sus mitos y símbolos heroicos ${ }^{66}$. El carácter esencialmente voluntarista fue reforzado por el discurso de "el retorno de los esclavos" y la memoria de la lucha mambí. La idea de que se estaba continuando una lucha de liberación creó un sentimiento de orgullo, al que se añadían los códigos de juventud y moralismo.

En Angola el internacionalismo cubano escribió sin duda su página más heroica. En ningún otro lugar del mundo se realizó con una dimensión tal el ideal revolucionario en que había sido forjada la conciencia de la generación insurgente cubana, la idea de un sacrificio sublime y fecundo, que implicaba incluso ofrendar la propia vida, en favor de la construcción de un horizonte emancipatorio para los pueblos del Tercer Mundo. De Angola, los internacionalistas cubanos no se llevaron oro, diamantes o petróleo, sino tan solo sus propios «hermanos caídos en el cumplimiento del deber» y «la entrañable amistad de esa nación» ${ }^{67}$. Para los cubanos Angola constituyó un "Girón africano", una derrota decisiva del imperialismo. En esa lucha se hundió el mito de la invulnerabilidad de los mercenarios blancos y los racistas sudafricanos, «el neocolonialismo perdió así uno de sus colmillos» ${ }^{68}$. "El mercenario cobra por matar. Su negocio es la guerra de agresión y el pillaje». Por el contrario, «el combatiente internacionalismo ofrenda su vida para que triunfen la libertad, la justicia y la paz». «El combatiente internacionalista siempre ha nacido del seno de la clase obrera, desde la Comuna de París a Angola, pasando por la guerra antifascista en España. Ha brotado también

\footnotetext{
${ }^{64}$ KRUIJT, Dirk. Cuba and the Revolutionary... Op. cit., pp. 189-190.

65 GARCÍA MÁRQUEZ, Gabriel. Operación Carlota (sobre Cuba y Angola). Revista Tricontinental. 1977, n. 53.

${ }^{66}$ RIBEIRO, Raquel. "Seremos (otra vez) como el Che?" Angola as an alternative narrative to Cuba in the 1970s. En: KIRK, Emily J.; CLAYFIELD, Anna, y STORY, Isabel (eds.). Cuba's forgotten decade. How the 1970s shaped the Revolution. Maryland: Lexington Books, 2018, pp. 209-225.

${ }^{67}$ CAMPOS, Pedro y ACOSTA, Marciel. Relatos de guerra: los héroes de Cuito Cuanavale. La Habana: Editorial de Ciencias Sociales, 2009, p. 137; VV. AA. La Guerra de Angola. La Habana: Editora Política, 1989, pp. 24-25.

${ }^{68}$ VV. AA. La Guerra de Angola. La Habana: Editora Política, 1989, p. 84.
} 
de los sectores populares permeados de la ideología de la fraternidad revolucionaria del proletariado 269 .

La continuidad con el carácter y el espíritu del proyecto revolucionario de los sesenta explica sin lugar a dudas el enorme apoyo social que concitó en la sociedad cubana. Silvio Rodríguez recuerda aquellos años «de cuando todo el mundo quería ir a Angola». En 1976 fue voluntario internacionalista y, como otros artistas cubanos, participó en actividades culturales en los frentes y en algunas ciudades. «Para mí aquella vivencia angolana fue muy seria»; «una de las lecciones inolvidables, para mí, fue ver la austeridad, el altruismo, la audacia y el desinterés con que el pueblo es capaz de ser internacionalista ${ }^{70}$. El historiador Piero Gleijeses señala que el servicio militar en Angola era muy popular entre los jóvenes. Un importante factor que contribuyó a este hecho era que los soldados y reservistas no estaban obligados a servir en una misión internacionalista, sino que podían negarse a ello sin tener que sufrir pena de cárcel o cumplir el servicio militar en otro país ${ }^{71}$.

La segunda gran intervención cubana en África tuvo lugar Etiopia a raíz de la invasión de ese país por la vecina Somalia - gobernada por Siad Barre, que contaba con el apoyo de Estados Unidos-. En total, fueron enviados 16.000 hombres para detener la agresión ${ }^{72}$. René García fue uno de esos soldados voluntarios desplegados en la región de Ogaden en 1977-1978. En la entrevista que mantuvimos nos relata el recuerdo de aquella experiencia y destaca el todavía presente compromiso internacionalista de los cubanos: «si no es militar, es en medicina, si no es como maestro, como constructor, para los ciclones». Al regreso de su misión, René se licenció y volvió a incorporarse a su trabajo como pescador:

«El que no ha ido allí no sabe lo que es el hambre y la necesidad, no sabe lo que es el maltrato a los negros (...). Yo volví y me di cuenta de que lo que allí había era una pobreza inmensa; en la ciudad donde yo estaba la mitad de las mujeres estaban en prostíbulos y los hombres nada más que trabajaban en el campo (...). Nosotros íbamos en una caravana y nos daban galleta; se la dábamos a los niños pequeños y otros grandes venían y se la quitaban para comérsela... ellos no sabían lo que era un caramelo o una fotografía; cuando se veían en ella, ellos se asombraban (...). Lo que sobraba de la comida tu ibas a un vertedero a botarlo y allí estaba una tonga de ellos con unas laticas y se lo comían así mismo fermentado y todo. Eso sí es hambre... Entonces aquí en Cuba siempre hay cuatro o cinco pelagatos que siempre se están quejando de la Revolución y no saben lo que es el hambre, no saben lo que es pasar trabajo ${ }^{73}$.

En Etiopia la intervención cubana aseguró la preservación de la integridad territorial de ese país. En Angola, sin embargo, la presencia cubana transformó el sur africano. Tras varios años de guerra irregular contra la UNITA, llegó la decisiva batalla de Cuito Cuanavale (diciembre de 1987-marzo de 1988) en la cual los cubanos se impusieron de forma aplastante a las fuerzas sudafricanas obligándolas a abrir las negociaciones de paz. En palabras de Nelson Mandela «la derrota del

\footnotetext{
69 Ibídem, pp. 100-101.

70 CASAUS, Víctor y ROGELIO NOGUERAS, Luis. Silvio... Op. cit., pp. 229-230.

${ }^{71}$ GLEIJESES, Piero. Visions of Freedom... Op. cit., pp. 517-518.

72 ZANETTI, Óscar. Historia mínima... Op. cit., p. 317.

${ }^{73}$ Entrevista de Óscar López Acón a René García (1943), La Habana, 23 de septiembre de 2019.
} 
ejército racista en Cuito Cuanavale permitió al pueblo de Namibia alcanzar la independencia» $y$ «sirvió de inspiración al pueblo de Sudáfrica»; «fue el Waterloo del apartheid $^{74}$. A todas luces, el papel geopolítico de Cuba fue extraordinario en el Tercer Mundo. Pero, para los internacionalistas cubanos «no era prestigio lo que se buscaba (...) lo que se buscaba era la solidaridad con esos pueblos»; "nosotros hicimos lo que considerábamos que era correcto en ese momento bajo la égida de Fidel Castro, que era un internacionalista convencido y que decía, y sabía, que nosotros solos no podíamos ganar ${ }^{75}$.

\subsection{Sobrevivientes: "Colgando de la brocha»}

A mediados de los años ochenta Cuba había iniciado un nuevo periodo para tratar de insuflar un nuevo dinamismo a la Revolución conocido como "Periodo de rectificación de errores y tendencias negativas" ${ }^{\prime 76}$. En 1986 Víctor Manuel González Albear formó parte de la delegación cubana invitada al XXVII Congreso del PCUS organizado por Gorbachov en Moscú entre el 25 de febrero y el 6 de marzo de ese año. En la entrevista que mantuvimos en La Habana recuerda los aires de renovación que se vivían ante la «crítica al estado de cosas»:

«Nuestro lenguaje era muy parecido al que allí se hablaba. Se decía: ahora estamos produciendo con menos efectividad que hace cincuenta años (...) Yo hice un artículo que se llamaba "Lenin estaba presente" por el que me pagaron como cien rublos, que era un buen dinero para la época... era verdad que era un congreso muy leninista. Nadie podía imaginar en ese momento que venía la hecatombe; era una denuncia a todos los males, una crítica a lo que estaba pasando. Parecía que iba a haber un movimiento muy renovador y para nosotros era como, bueno, en eso estamos nosotros, desafiando "el espíritu santo"; se podía hablar y decir que el socialismo tenía muchas maneras; el socialismo no es uno solo; hay muchas maneras... aquello era muy estimulante (...) Y en esas, vino la hecatombe, nosotros decíamos que era como el pintor dando brocha en una pared, encaramado a una escalera y le quitan la escalera, y se queda colgado de la brocha. Nosotros nos quedamos colgados de la brocha. Aquello fue terrible ${ }^{77}$.

La enorme crisis social en que se vió sumida Cuba en la década de los años noventa con la desaparición de la Unión Soviética y el bloque de países del COMECON obligó a redefinir la "esencia" de la Revolución. En 1990 se decretó el «Periodo Especial en tiempo de paz». El imperativo "salvar las conquistas sociales de la Revolución" llevaba a pensar que debía sacrificarse y que debía preservarse. Fue ahora cuando las ideas y los escritos del Che Guevara, soslayados en gran medida en la década de institucionalización anterior, fueron sometidos a un renovado enfoque. El voluntarismo, la movilización y los estímulos morales que presidieron el decenio de 1960 se situaron en primer plano. Se consideró que esa década había encapsulado las esencias de la Revolución: participación activa,

\footnotetext{
${ }^{74}$ CAMPOS, Pedro y ACOSTA, Marciel. Relatos de guerra... Op. cit., p. 131.

75 Entrevista de Óscar López Acón a Ángel Jiménez González (1938), La Habana, 8 de octubre de 2019.

${ }^{76}$ GUERRA VILABOY, Sergio y MALDONADO GALLARDO, Alejo. Historia de la revolución cubana. Tafalla: Txalaparta, 2009, pp. 134-135.

77 Entrevista de Óscar López Acón a Víctor Manuel González Alvear (1940), La Habana, 18 de septiembre de 2019.
} 
idealismo, nacionalismo y cambio radical. En esos orígenes se encontraban las raíces del ethos de la Revolución. La coherencia continua de la ideología nacionalista (cubanía), anclada en una larga tradición de disidencia radical, que se remontaba a las luchas anticoloniales del XIX, a la radicalización de principios de siglo XX y a los años cincuenta, permitió a las generaciones sucesivas reclamar su herencia, como plantea Antoni Kapcia ${ }^{78}$.

Quedó claro, que la Revolución todavía tenía ciertas bases sólidas con las que resistir al colapso. El socialismo en Cuba no había venido de la mano de las divisiones soviéticas, como en Europa del Este, sino que había sido un producto de hondas luchas sociales contra la dictadura de Fulgencio Batista ${ }^{79}$. En este contexto de rearme ideológico, cabe inscribir la fundación de la Asociación de Combatientes de la Revolución Cubana (ACRC) en 1993, que pasó a ser presidida por el Comandante de la Revolución Juan Almeida Bosque y alcanzó los 300.000 miembros en $2003^{80}$. Pronto se convirtió en un foro de debate e instrumento de movilización a nivel nacional y local. En su seno, se incluían desde algunos miembros de las Brigadas Internacionales que combatieron al lado de la República española durante la Guerra Civil de 1936-1939, pasando por los veteranos de las lucha contra Batista, contra la invasión de bahía de Cochinos y contra las guerrillas del Escambray, hasta los combatientes internacionalistas de África y América Latina.

La nueva atmósfera de amenaza, división social y asedio —intensificado por las leyes estadounidenses Torricelli (1992) y Helms-Burton (1996) - conectaba con la experiencia colectiva de los inicios de la Revolución y el sentido de solidaridad y lucha comunal. Se sumaba una idea de moral comunitaria, basada en el apoyo al prójimo y la solidaridad, que subrayaba también el papel central de la familia como unidad social ${ }^{81}$. Pero, pero encima de todo, subyacía a todos estos mecanismos el que se presenta como más fundamental, y que no es otro que el continuo poder ideológico de los mitos políticos de la Revolución; entendiendo estos como el conjunto de valores cohesivos transmitidos y perpetuados través de la generaciones, e interiorizados a nivel individual. La soberanía y la independencia como los principios rectores de la Revolución conectaban directamente con el siglo XIX y el espíritu de los mambises. Se acentuaba la moral de auto-sacrificio —como rezaba el himno nacional cubano de 1902: «jMorir por la patria es vivir!»-, que encarnaba José Martí; y había reactualizado el ejemplo del Che, a través de su historia de abnegación y entrega, que concluía en 1997 con el retorno a Cuba de sus restos mortales.

Asimismo, socialismo significaba, por sobre todas las cosas, la idea de «salvar vidas», en forma de atención médica y educación gratuita, pero también ante la catástrofe climática, denunciada por Fidel Castro, que siguió encarnando ese ethos

\footnotetext{
${ }^{78} \mathrm{KAPCIA}$, Antoni. Educational Revolution and revolutionary morality in Cuba: the "New man", youth and the new "Battle of Ideas". Journal of Moral Education. 2005, vol. 3, n. 4, p. 406.

${ }^{79}$ BELL LARA, José, CARAM LEÓN, Tania, KRUIJT, Dirk y LÓPEZ GACÍA. Cuba: Periodo especial... Op. cit., p. 43.

${ }^{80}$ KAPCIA, Antoni. Cuba in Revolution... Op. cit., p. 174.

${ }^{81} \mathrm{KAPCI}$, Antoni. Educational Revolution... Op. cit.
} 
revolucionario ${ }^{82}$. En palabras de René García, el «enorme poder de inteligencia, de asimilación, de visión lejana, de ver los problemas; y muestra de todo ello era que todo el mundo oía lo que decía Fidel. Él vio cosas en aquella etapa que hoy se hacen realidad... esto mismo de hoy, del cambio climático lo planteo él, y en aquel momento decían que estaba loco" ${ }^{83}$. Lo cierto es que, durante el "Periodo Especial" Cuba no solo no dejó de proveer asistencia médica a los más desfavorecidos; sino que incrementó el número de brigadas médicas en las regiones más pobres de América Latina, el Caribe y África, además de expandir otras iniciativas. En 1999 se inauguró en La Habana la Escuela Latinoamericana de Ciencias Médicas (ELAM), que acogió a estudiantes de dieciocho países latinoamericanos y caribeños. A partir del año 2000 también a alumnado proveniente de otros continentes (noventa y ocho países en 2012) ${ }^{84}$.

\section{3. «Memorias fuertes»: el testimonio de la última generación insurgente cubana}

Las historias de vida nos acercan a seres conscientes que se construyen constantemente en su proceso de vida real. La experiencia, como escribió el historiador E. P. Thompson, «irrumpe sin llamar a la puerta». Y es que, es en ese espacio donde el ser humano vive su realidad material, percibida y significada a partir de los acervos culturales que a su vez son transformados y resignificados por la vivencia de lo real ${ }^{85}$.

En 1955 Ángel Fernández Vila estudiaba medicina en la Universidad de La Habana gracias a una beca de matrícula por las calificaciones obtenidas en el preuniversitario. Durante los años de preparatoria para la Universidad Ángel había trabajado de tornero mecánico en una fábrica durante la noche. La carrera era cara, había que comprar los libros y gastarse «no menos de quinientos o seiscientos dólares», por lo que tuvo que seguir trabajando. Un día, el decano de la facultad le dijo: «mire joven, la Universidad no es para hacer eso que usted está haciendo, o se estudia, o se trabaja, escoja usted; entonces, —relata - me botó de la Universidad porque no podía dejar de trabajar». En ese momento la Universidad de La Habana era el epicentro de la lucha política contra la dictadura. Fernández Vila pasó entonces a la movilización de los estudiantes y a la lucha clandestina:

«Empezamos en el Directorio, y luego en el Movimiento 26 de Julio. La policía nos recibía a tiros, en San Lázaro e Infanta nos caían a tiros en las manifestaciones (...). Luego, la lucha era con pistolas, bombas, fusiles, dentro de la ciudad. Yo estuve en La Habana tres años sin ver a mi familia; primero como responsable de propaganda, luego Delegado Nacional de Propaganda (...) ya en el 58, después del fracaso de la huelga de abril, la Dirección Nacional me envía a Oriente, entonces me quedo como segundo jefe de Radio Rebelde en la "Columna 1", y

\footnotetext{
${ }^{82}$ WILKINSON, Stephen. Ideology and Power in the Cuban State. En: FONT Mauricio A. Chaning Cuba/Changin World. New York: Bildner Center for Western Hemisphere Studies, 2008, p. 14.

${ }^{83}$ Entrevista de Óscar López Acón a René García (1943), La Habana, 23 de septiembre de 2019.

${ }^{84}$ El personal médico cubano destinado en el extranjero se incrementó desde finales de los años noventa: 3.000 en 1999, 3.800 en 2001, 15.000 en 2003, 25.000 en 2005 y 30.000 en 2007. KRUIJT, Dirk. Cuba and the Revolutionary... Op. cit., p. 190 y p. 207.

${ }^{85}$ THOMPSON, Edward P. Miseria de la teoría... Op. cit., p. 21 y pp. 253-269.
} 
participo en el combate como médico».

En 1965, el que un día fuera un joven mecánico tornero terminó sus estudios de medicina, formando parte de la primera graduación de médicos cubanos. Al año siguiente marchó a Vietnam como jefe de la misión médica cubana, donde conoció Hô Chi Ming. Posteriormente, alcanzó elevados puestos en los servicios médicos de las FAR y fue nombrado Director de la Escuela de Medicina y la Facultad de Ciencias Médicas de La Habana (1971). En 1987 cumplió una segunda misión internacionalista, en esta ocasión como jefe de los servicios médicos de la misión militar cubana en Angola, donde fue reconocido por su contribución en el combate de la epidemia del cólera. Hoy día, a sus ochenta y siete años, Ángel Fernández Vila continúa ejerciendo como profesor consultante en la Universidad de La Habana ${ }^{86}$.

Otra trayectoria de vida evidencia lo profundo de los cambios acontecidos con la Revolución. En 1959 Antonio Díaz Ruiz fue nombrado dirigente obrero en Santa Clara, desde donde pasó a una Escuela de Instrucción Revolucionaria. "Yo empecé a ser profesor sin tener título de profesor. Yo era bachiller. Con las condiciones que existían yo tenía un nivel de cultura general alto en relación con el resto de la población». Más tarde fue seleccionado para ser Director de la Escuela Nacional del Partido en la provincia de Las Villas. El primer grupo al que impartió magisterio,

«fue el grupo que seleccionó Raúl [Castro] de quince comandantes de la Revolución. Todos eran de la Sierra Maestra... estaba Almeida como jefe del grupo y quince comandantes más. Ellos eran prácticamente analfabetos. Habían sido combatientes pero no conocían nada de política, ni de historia. Yo les di la economía política y empezaron a entender toda la situación que había pasado en Cuba. La dominación colonial y la dominación neocolonial de Estados Unidos. Leopoldo Cintra Frías fue uno de esos quince comandantes; fue alumno mío, el que hoy es Ministro de las Fuerzas Armadas».

Antonio Díaz asumió la dirección del Departamento de Educación Interna del Comité Central del PCC. Se especializó en el estudio de la economía y realizó un doctorado en Moscú con el tema "El trabajo ideológico en Cuba. Apuntes para su estudio". Después de terminar una misión internacionalista civil en Angola, fue enviado a Praga como representante del Comité Central, donde permaneció hasta 1990, momento en que regresó a La Habana y pasó a trabajar en la Universidad, donde continúa como profesor consultante. Su compañero y amigo, el historiador Arnaldo Silva León, se ocupó de dirigir la sección de planes y programas de estudios de su Departamento. Bajo la dirección de Jorge Risquet, Arnaldo Silva desempeñó una misión civil en Angola. Posteriormente, desarrolló una trayectoria académica muy destacada. De entre sus numerosas publicaciones, escribió junto con José Cantón Historia de Cuba. Liberación Nacional y socialismo, obra de cabecera de los estudiantes de historia del pre-universitario ${ }^{87}$. Todavía hoy, aun habiendo perdido la

${ }^{86}$ Entrevista de Óscar López Acón a Ángel Fernández Vila (1932), La Habana, 19 de octubre de 2019. DÁVILA RODRíGUEZ, Ildre. Dr. Ángel Fernández Vila: Medicina y Revolución. Revista Habanera de Ciencias Médicas. Jul./ Ago. 2019, vol. 18, n. 4, pp. 571-578.

${ }^{87}$ Recientemente reeditada, SILVA LEÓN, Arnaldo. Breve historia de la Revolución cubana (19592000). La Habana: Félix Varela, 2019 [2003]. La obra de síntesis más difundida de CANTÓN NAVARRO, José. Historia de Cuba. El desafío del yugo y la estrella. La Habana: Editorial SI-MAR, 2001, ha sido publicada en varios idiomas, incluyendo el alemán y el ruso. Una visión de idénticas 
visión, continúa impartiendo su magisterio como profesor consultante. Otro de nuestros entrevistados, Víctor Manuel González Albear, se define como un «militante activo, despierto y dormido»; y sigue trabajando como periodista en la edición digital de la Revista Bohemia y coordinando el CDR de su distrito, en Nuevo Vedado (La Habana). Carlos Menéndez se licenció gracias a una beca en Economía del Comercio Exterior en la República Democrática Alemana en 1965 y trabajó en el Ministerio del Comercio de Cuba. En 2012 colaboró en la publicación las memorias de su mejor amigo caído en combate en los últimos días de la dictadura, el dirigente de la Federación Estudiantil Universitaria Pepe Garcearán, encumbrado a "mártir de la Revolución". Todavía habita en su memoria el recuerdo de aquel trágico día: «el murió tratando de sabotear un puente con dinamita. Era la guerra. Fue el 17 de diciembre. Doce días antes de la caída de Batista. Díez días después nació su hija, María Eugenia. A mí me tocó la infausta tarea de írselo a decir a su madre y a su abuela de que había muerto... Fue el día más negro de toda mi vida» ${ }^{88}$.

Nuestros interlocutores, que integran la última generación insurgente cubana, tuvieron trayectorias profesionales muy destacadas y vivieron de primera mano acontecimientos históricos muy significativos, desempeñando puestos relevantes de índole política, militar y académica. A rasgos generales, podemos decir que algunos de ellos acabaron conformando la élite de la Revolución. La unidad generacional entre ellos no viene determinada mecánicamente por haber nacido cronológicamente en el mismo tiempo, sino «por la posibilidad de participar en los mismos sucesos, en los mismos contenidos vitales y de hacerlo a partir de la misma modalidad de estratificación de la experiencia», es decir, por haber participado en las corrientes sociales que constituían el tiempo histórico en el que se encontraban ${ }^{89}$.

Sus recuerdos individuales se hallan inscritos en un relato colectivo. Tal y como postuló Maurice Halbwachs, no es el individuo aislado el que acomete el proceso de rememoración, sino que la experiencia individual se inserta en la colectiva por medio de marcos sociales portadores de representaciones, significados y valores de la sociedad y la cultura. Así, la memoria colectiva se desarrolla como producto de interacciones múltiples, de entretejimiento de memorias individuales y tradiciones compartidas $^{90}$. Por su parte, Paul Ricoeur hace hincapié en el hecho de que la memoria se encuentra siempre proyectada en la vida pública. La memoria se asienta en el plano de la experiencia presente, donde el recuerdo se construye - tras un proceso de selección y reinterpretación, preñado de olvidos y silencios- según

\footnotetext{
pretensiones, con claro afán divulgativo, es la que ofrece LÓPEZ CIVEIRA, Francisca. Cien preguntas sobre la Historia de Cuba. La Habana: Editorial Gente Nueva, 2011.

${ }^{88}$ Entrevista de Óscar López Acón a Carlos Manuel Menéndez Lara (1936), La Habana, 3 de octubre de 2019. GARCERÁN DE VALL, María Eugenia y MENÉNDEZ LARA, Carlos M. Reencuentro con Pepe Garcerán. En busca de un joven y su tiempo. La Habana: Centro Cultural Pablo de la Torriente Brau, 2012; MENÉNDEZ LARA, Carlos M. Anécdotas de Pepe Garcerán y el Frente de La Habana. En: DÁMASO ABREU, Julio y GARCÍA BERTRAND, José A. (comps.). Relatos de la lucha insurreccional 1952-1958 en las barriadas habaneras, Segunda Parte. La Habana: Fondo documental ACRC y Centro cultural Pablo de la Torriente Brau, 2019, pp. 48-52.

${ }^{89}$ MARTÍN ÁLVAREZ, Alberto y REY TRISTÁN, Eduardo. La oleada revolucionaria... Op. cit., p. 21.

90 HALBWACHS, Maurice. La memoria colectiva. Zaragoza: Prensas Universitarias de Zaragoza, 2004, pp. $45-46$, p. 54 y p. 70 [1950].
} 
determinadas sensibilidades políticas, culturales y éticas ${ }^{91}$. Sus memorias hallaron legitimidad y reconocimiento dentro del discurso oficial del nuevo orden revolucionario. Se entroncan y se metamorfosean así con la narrativa dominante, por lo que tienen un «carácter estructurante» sobre la demás, puesto que son expresión, a su vez, de un proyecto de presente y futuro por cuanto «usos públicos» de estas memorias. Se trata de «memorias fuertes», usando la denominación de Traverso, alimentadas por políticas públicas, rituales cívicos, conmemoraciones, efemérides y reproducidas en el marco de las instituciones culturales, educativas y científicas ${ }^{92}$.

La «memoria comunicativa» - la memoria del recuerdo vivo-, que se articula en la comunicación cotidiana y el lenguaje informal en grupos de parentesco, familiares y afectivos; y posibilita, mediante el mismo acto de la rememoración, que el individuo adquiera conciencia de su identidad, a nivel personal y colectivo, abarca ente tres y cuatro generaciones, es decir, aproximadamente ochenta o cien años ${ }^{93}$. Sin embargo, la «memoria cultural» sobrevive cuando ya no hay testigos, ni coetáneos al acontecimiento, trascendiendo diversas épocas. La memoria colectiva de la última generación insurgente cubana pertenece a esta última categoría. «Nosotros —relata Ángel Fernández Vila - surgimos de las universidades y nos convertimos en revolucionarios, hicimos gobierno y ahora ya está pasando la época nuestra. En veinticinco años ya no quedará ninguno de nosotros vivos; es así; va a quedar esta historia.... ${ }^{94}$.

\section{Consideraciones finales}

Los testimonios que hemos explorado devuelven el protagonismo a sujetos visibles que se enfrentaron a su propio tiempo. $\mathrm{Y}$, nos permiten, si no rescribir la historia, al menos sí poner rostros de carne y hueso a sus hacedores. De igual modo, las historias de vida nos abren nuevas ventanas a la experiencia vivida de la Revolución, y nos ayudan a comprender el significado mismo de ese proceso histórico. Necesariamente, la aproximación que hemos realizado constituye un acercamiento parcial y fragmentario del "todo" que nunca puede agotarse en sí misma.

Las fuentes orales, por su naturaleza, cuestionan cualquier intento de concebir la realidad socio-histórica tanto como el resultado de "estructuras objetivas" puras o

\footnotetext{
91 RICOEUR, Paul. La lectura del tiempo pasado: memoria y olvido. Madrid: Ediciones de la Universidad Autónoma de Madrid, 1999, p. 18. La socióloga Elizabeth Jelin propone entender "las memorias" como "procesos subjetivos anclados en experiencias y marcas materiales», y subraya la importancia de "historizar las memorias», o reconocer que se producen cambios históricos en el sentido del pasado, ligados a climas culturales y luchas políticas del presente. JELIN, Elizabeth. Los trabajos de la memoria. Madrid: Siglo XXI, 2002, pp.17-22.

${ }^{92}$ Enzo Traverso hace extensible el siguiente aforismo en lo relativo a las memorias, según el cual, la única diferencia entre una lengua y un dialecto se debe a que la lengua está protegida por una institución. La visibilidad y el reconocimiento de una memoria depende en última instancia de la fuerza de quienes la portan TRAVERSO, Enzo. El pasado, instrucciones de uso: historia, memoria y política. Madrid: Marcial Pons, 2007, p. 49.

93 ASSMANN, Jan y CZAPLICKA, John. Collective Memory and Cultural Identity. New German Critique. Spring-Summer 1995, n. 65, pp. 125-133.

94 Entrevista de Óscar López Acón a Ángel Fernández Vila (1932), La Habana, 19 de octubre de 2019.
} 
como el resultado de la acción subjetiva pura. Es mediante la praxis del sujeto como puede captarse mejor la experiencia y la subjetividad para fines históricos; y, asimismo, examinar la complejidad de procesos como la génesis de las identidades, las representaciones colectivas o el propio fenómeno de construcción de memorias. Todo ello problemáticas fundamentales de la historia del tiempo presente $e^{95}$. A través de las historias de vida podemos indagar en la genealogía del "yo" o en la construcción de las subjetividades, esto es, investigar las formas culturales y los procesos mediante los cuales los individuos expresan su sentido de sí mismos en la historia ${ }^{96}$.

Por otro lado, con toda certeza, desde el momento en que la experiencia vital de todo tipo de gente puede utilizarse como materia prima de la historia, esta adquiere una nueva dimensión, en su más amplio sentido, «se vuelve más plural, más social y democrática», como postula Paul Thompson ${ }^{97}$. A este respecto, cabe abogar por el desarrollo de enfoques que aborden «desde abajo» y «desde dentro» el proceso histórico de la Revolución cubana, incluyendo la pluralidad de voces y experiencias sociales. Las palabras proferidas por gente de toda condición imprimen a la historia un aliento vital: « ¿si en algo te sirve eso? algunas cosas te servirán... otras, como yo hablo así tan dicharachero a lo mejor hay cosas que no deben salir en ningún lado» ${ }^{98}$.

\section{Entrevistas orales}

Entrevista de Óscar López Acón a Víctor Manuel González Alvear (1940), La Habana, 18 de septiembre de 2019.

Entrevista de Óscar López Acón a René García (1943), La Habana, 23 de septiembre de 2019.

Entrevista de Óscar López Acón a Arnaldo Silva León (1938), La Habana, 2 de octubre de 2019.

Entrevista de Óscar López Acón a Carlos Manuel Menéndez Lara (1936), La Habana, 3 de octubre de 2019.

Entrevista de Óscar López Acón a Justo Gimeno (1939), La Habana, 7 de octubre de 2019.

Entrevista de Óscar López Acón a Antonio Díaz Ruiz (1930), La Habana, 7 de octubre de 2019.

Entrevista de Óscar López Acón a Ángel Jiménez González (1938), La Habana, 8 de

\footnotetext{
${ }^{95}$ BÉDARIDA, François. Definición, método y práctica de la Historia del tiempo presente. Cuadernos de Historia Contemporánea. 1998, n. 20, pp. 19-27.

${ }^{96}$ La noción de "genealogía de la subjetivación", tomada FOUCAULT, Michel. Microfísica del poder. Madrid: La Piqueta, 1978, pp. 167-168.

97 THOMPSON, Paul. La voz del pasado. Historia oral. Valencia: Alfons el Magnànim, 1998, p. 296 [1978].

${ }^{98}$ Entrevista de Óscar López Acón a René García (1943), La Habana, 23 de septiembre de 2019.
} 
octubre de 2019.

Entrevista de Óscar López Acón a Víctor Manuel González Albear (1940), La Habana, 18 de octubre de 2019.

Entrevista de Óscar López Acón a Ángel Fernández Vila (1932), La Habana, 19 de octubre de 2019.

\section{Bibliografía}

ALCÁZAR GARRIDO, Joan del (ed.). Historia actual de América latina 1959-2009. Valencia: Tirant lo Blanch, 2011.

ASSMANN, Jan y CZAPLICKA, John. Collective Memory and Cultural Identity. New German Critique. Spring-Summer 1995, n. 65, pp. 125-133.

BALFOUR, Sebastian. Fidel Castro. Una biografía política. Barcelona: Península, 2009.

BARELA, Liliana; MIGUEZ, Mercedes y GARCÍA CONDE Luis. Algunos apuntes sobre historia oral. Buenos Aires: Instituto Histórico de la Ciudad de Buenos Aires, 2004.

BELL LARA, José [et al.]. Cuba: Periodo especial. La Habana: Editorial UH, 2017.

BÉDARIDA, François. Definición, método y práctica de la Historia del tiempo presente. Cuadernos de Historia Contemporánea. 1998, n. 20, pp. 19-27.

CANCINO, Hugo. El discurso ideológico de la Revolución cubana. Para un estudio de las raíces histórico-ideológicas de la revolución. Histórica: Debates e Tendências. Ene./Jun. 2010, vol. 10, n. 1, pp. 73-86.

CAMPOS, Pedro y ACOSTA, Marciel. Relatos de guerra: los héroes de Cuito Cuanavale. La Habana: Editorial de Ciencias Sociales, 2009.

CANTÓN NAVARRO, José. Historia de Cuba. El desafío del yugo y la estrella. La Habana: Editorial SI-MAR, 2001.

CANTÓN NAVARRO, José y SILVA LEÓN, Arnaldo. Historia de Cuba 1959-1999. Liberación Nacional y socialismo. La Habana: Editorial Pueblo y Nación, 2018 [2009].

CASAUS, Víctor y ROGELIO NOGUERAS, Luis. Silvio: Que levante la mano la guitarra. La Habana: Centro Cultural Pablo de la Torriente Brau, 2017.

DÁVILA RODRÍGUEZ, Ildre. Dr. Ángel Fernández Vila: Medicina y Revolución. Revista Habanera de Ciencias Médicas. Jul./ Ago. 2019, vol. 18, n. 4, pp. 571 578. 
DÍEZ ACOSTA, Tomás. La guerra sucia contra Cuba. Documentos del gobierno de EE.UU. sobre la Operación Mangosta. Tomo 1. La Habana: Editora Política, 2018.

DORE, Elizabeth. Historia oral y vida cotidiana en Cuba. Nueva sociedad. 2012, n. 242, pp. 36-55.

FANON, Frantz. Los condenados de la tierra. Tafalla: Txalaparta, 2018 [1961].

FERNÁNDEZ VILA, Ángel. Por las ideas del Moncada. Relatos. La Habana: Verde Olivo, 2013.

FOLGUERA, Pilar. Cómo se hace historia oral. Madrid: Eudema, 1994.

FOUCAULT, Michel. Microfísica del poder. Madrid: La Piqueta, 1978.

FRASER, Ronald. La Historia oral como historia desde abajo. Ayer. 1993, n. 12, pp. 79-92.

FREIRE, Paulo. Pedagogía del oprimido. Madrid: Siglo XXI, 2019 [1970].

GARCERÁN DE VALL, María Eugenia y MENÉNDEZ LARA, Carlos M. Reencuentro con Pepe Garcerán. En busca de un joven y su tiempo. La Habana: Centro Cultural Pablo de la Torriente Brau, 2012.

GARCÍA MÁRQUEZ, Gabriel. Operación Carlota (sobre Cuba y Angola). Revista Tricontinental. 1977, n. 53.

GARCÍA-NIETO, María del Carmen. Valor y potencia de la fuente oral. En: GARCÍANIETO María del Carmen; VÁZQUEZ DE PRAGA, María José y VILANOVA, Mercedes (eds.). Historia, fuente y archivo oral. Actas del Seminario "Diseño de proyectos de Historia Oral». Madrid: Ministerio de Cultura, 1990, pp. 41-69.

GLEIJESES, Piero. Conflicting Missions: Havana, Washington and Africa, 19591976. Chapel Hill: University of North Carolina Press, 2001.

GLEIJESES, Piero. Visions of Freedom: Havana, Washington, Pretoria, and the Struggle for Southern Africa, 1976-1991. Chapel Hill: University of North Carolina Press, 2013.

GONZÁLEZ AROCHA, Jorge. Sartre y el mundo encantado de la libertad. En: GÓMEZ VELÁZQUEZ, Natasha y VILÁ BLANCO, Dolores. Pensar Cuba hoy: forzando los bordes. La Habana: Editorial UH, 2018, pp. 59-88.

GUERRA VILABOY, Sergio. Las revoluciones latinoamericanas del siglo XX desde la historia comparada. SÉMATA. 2016, n. 28, pp. 299-319.

GUERRA VILABOY, Sergio y MALDONADO GALLARDO, Alejo. Historia de la 
revolución cubana. Tafalla: Txalaparta, 2009.

GUEVARA, Ernesto Che. Pasajes de la Guerra Revolucionaria. Tafalla: Txalaparta, 1997 [1963].

GUEVARA, Ernesto Che. Cuba: ¿Excepción histórica o vanguardia en la lucha anticolonialista? En: GUEVARA, Ernesto Che. Mis sueños no tendrán fronteras. Compilación de María del Carmen Ariet García. La Habana: Centro de Estudios Che Guevara, 2011, pp. 125-141 [publicado originalmente en la Revista Verde Olivo el 9 de abril de 1961].

GUEVARA, Ernesto Che. En las Naciones Unidas (11 de diciembre de 1964). En: GUEVARA, Ernesto Che. Solidaridad e internacionalismo. La Habana: Editorial de Ciencias sociales, 2018, pp. 43-71.

HALBWACHS, Maurice. La memoria colectiva. Zaragoza: Prensas Universitarias de Zaragoza, 2004 [1950].

HARNECKER, Marta. Pinceladas de la historia de Cuba (Testimonios de 19 abuelos). La Habana: Instituto Cubano del Libro; Editorial de Ciencias Sociales, 2003.

HOBSBAWM, Eric. Los horizontes de Cuba. En: HOBSBAWM, Eric. ¡Viva la Revolución! Sobre América Latina. Edición y compilación de L. Bethell. Barcelona: Crítica, 2018, pp. 37-41.

HUBERMAN, Leo y SWEEZY, Paul M. Cuba. Anatomía de una Revolución. Buenos Aires; Montevideo: Palestra, 1961.

JELIN, Elizabeth. Los trabajos de la memoria. Madrid: Siglo XXI, 2002.

KAPCIA, Antoni. Ideology and the Cuban Revolution: Myth, Icon and Identity. En: FOWLER, William (ed.). Ideologues and ideologies in Latin America. Greenwood: Westport, 1997, pp. 83-104.

KAPCIA, Antoni. Educational Revolution and revolutionary morality in Cuba: the "New man", youth and the new "Battle of Ideas". Journal of Moral Education. 2005, vol. 3, n. 4, pp. 399-412.

KAPCIA, Antoni. Cuba in Revolution. A history since the fifties. London: Reaktion Books, 2008.

KAROL, K. S. Los guerrilleros en el poder. Barcelona: Seix Barral, 1972.

KOSELLECK, Reinhart. Futuro pasado: para una semántica de los tiempos históricos. Barcelona: Paidós, 1993 [1979].

KRUIJT, Dirk. Cuba and the Revolutionary Latin American: An oral history. London: Zed Books, 2017. 
LEWIS, Oscar; LEWIS, Ruth M. y RIGDON, Susan M. Viviendo la revolución: una historia oral de Cuba contemporánea: cuatro hombres. México: Joaquín Mortiz, 1980.

LEWIS, Oscar, LEWIS; Ruth M. y RIGDON, Susan M. Cuatro mujeres. Vivencias durante la Revolución cubana. Madrid: Plaza \& Janés, 1980.

Ley 1129 del 26 de noviembre de 1963 del Servicio Militar Obligatorio (SMO). En: Leyes del gobierno revolucionario de Cuba: Folletos de divulgación legislativa. 1963, n. 50.

LÓPEZ-ÁVALOS, Martín. La cultura política de la vanguardia o la construcción del ethos revolucionario. Cuba 1952-1959. TZINTZUN. Ene./Jun. 2011, n. 53, pp. 75-105.

LÓPEZ CIVEIRA, Francisca. Cien preguntas sobre la Historia de Cuba. La Habana: Editorial Gente Nueva, 2011.

LLONA, Miren. Historia, memoria y oralidad. En: LEONÉ, Santiago y MENDIOLA, Fernando (coords.). Voces e imágenes en la historia. Fuentes orales y visuales. Investigación histórica y renovación pedagógicas. Pamplona: Universidad de Navarra, 2007, pp. 53-57.

LÖWY, Michael. El pensamiento del Che Guevara. Madrid: Siglo XXI, 2007 [1970].

LÖWY, Michael. El marxismo en América Latina. Santiago de Chile: LOM Ediciones, 2007.

M. G. C. Me quiero inscribir ¡Ya! en el SMO. Bohemia. 1963, (29 Noviembre), pp. 1819.

MARTÍN ÁLVAREZ, Alberto y REY TRISTÁN, Eduardo. La oleada revolucionaria latinoamericana contemporánea, 1959-1996. Definición, caracterización y algunas claves para su análisis. Naveg@mérica. Revista electrónica de la Asociación Española de Americanistas [en línea]. 2012, n. 9, pp. 1-36. [Fecha de $\begin{array}{lcr}\text { consulta: } & \text { 30-08-2020]. } & \text { Disponible } \\ <\text { https://revistas.um.es/navegamerica/article/view/161591/141091>. }\end{array}$

MENÉNDEZ LARA, Carlos $M$. Anécdotas de Pepe Garcerán y el Frente de La Habana. En: DÁMASO ABREU, Julio y GARCÍA BERTRAND, José A. (comps.). Relatos de la lucha insurreccional $1952-1958$ en las barriadas habaneras, Segunda Parte. La Habana: Fondo documental ACRC y Centro cultural Pablo de la Torriente Brau, 2019, pp. 48-52.

MIRES, Fernando. La rebelión permanente. Las revoluciones sociales en América Latina, Madrid: Siglo XXI, 2011 [1988].

PASSERINI, Luisa. Memoria y utopía. La primacía de la intersubjetividad. Valencia: 
Publicacions Universitat de València, 2006.

PINO MACHADO, Quintín. La batalla de Girón. Razones de una victoria. La Habana: Editorial de Ciencias Sociales, 1983.

PLAMPER, Jan. Historias de las emociones: caminos y retos. Cuadernos de Historia Contemporánea. 2014, n. 6, pp. 17-29.

RAMÍREZ CHICHARRO, Manuel. Llamada a las armas. Las mujeres en la Revolución cubana 1952-1959. Madrid: Doce Calles, 2019.

RAMONET, Ignacio. Fidel Castro. Biografía a dos voces. Barcelona: Debate, 2016 [2004].

REDDY, William M. The Navigation of Feeling: A Framework for the History of Emotions. New York: Cambridge University Press, 2001.

REGALADO, Antero. Las luchas campesinas en Cuba. La Habana: Editorial Orbe, 1976.

RIBEIRO, Raquel. "Seremos (otra vez) como el Che?" Angola as an alternative narrative to Cuba in the 1970s. En: KIRK, Emily J.; CLAYFIELD, Anna, y STORY, Isabel (eds.). Cuba's forgotten decade. How the 1970s shaped the Revolution. Maryland: Lexington Books, 2018, pp. 209-225.

RICOEUR, Paul. La lectura del tiempo pasado: memoria y olvido. Madrid: Ediciones de la Universidad Autónoma de Madrid, 1999.

ROBIN, Regine. ¿Cede la historia oral la palabra a quienes están privados de ella, o es la historia de vida un espacio al margen del poder? En: VILANOVA, Mercedes (ed.). El poder en la sociedad. Historia y fuente oral. Barcelona: Antoni Bosch editor, 1986, pp. 195-203.

RODRÍGUEZ CRUZ, Juan Carlos. Hombres del Escambray. Los secretos de la victoria. La Habana: Capitán San Luis, 2015.

RODRÍGUEZ, Javier. Entusiasmo popular en la inscripción para el servicio militar. Bohemia. 1963, (6 Diciembre), pp. 68-70.

ROJAS GUTIÉRREZ, Rafael. Historia mínima de la Revolución cubana. Madrid: Turner, 2015.

SCHULTZ, Rainer. La historiografía sobre Cuba más allá de la isla (1993-2018). Temas. Jul./Dic. 2017, n. 91-92, pp. 13-20.

SIERRA MADERO, Abel. El trabajo os hará hombres: Masculinización nacional, trabajo forzado y control social en Cuba durante los años sesenta. Cuban Studies. 2016, n. 44, pp. 309-349. 
SILVA LEÓN, Arnaldo. Breve historia de la Revolución cubana (1959-2000). La Habana: Félix Varela, 2019 [2003].

SUÁREZ AMADOR, José. En los umbrales de la Revolución. Terrorismo y bandidismo en Occidente (1959-1965). La Habana: Editorial Ciencias Sociales, 2018.

TAIBO II, Paco Ignacio. Ernesto Guevara, también conocido como el Che. Barcelona: Crítica, 2017 [1996].

THOMPSON, Edward P. Miseria de la teoría. Barcelona: Crítica, 1981 [1978].

THOMPSON, Paul. La voz del pasado. Historia oral. Valencia: Alfons el Magnànim, 1998 [1978].

THOMPSON, Paul. Historia, memoria y pasado reciente. Escuela de Historia. Universidad Nacional de Rosario. 2003/2004, n. 20, pp. 15-34.

TRAVERSO, Enzo. El pasado, instrucciones de uso: historia, memoria y política. Madrid: Marcial Pons, 2007.

TREBITSCH, Michel. El acontecimiento. Clave para el análisis del tiempo presente. Cuadernos de Historia Contemporánea. 1998, n. 20, pp. 29-40.

VV. AA. La Guerra de Angola. La Habana: Editora Política, 1989.

VALDÉS VIVÓ, Raúl. Angola: fin del mito de los mercenarios. La Habana: Editorial de Ciencias Sociales, 1976.

WILKINSON, Stephen. Ideology and Power in the Cuban State. En: FONT Mauricio A. Chaning Cuba/Changin World. New York: Bildner Center for Western Hemisphere Studies, 2008, pp. 11-22.

ZANETTI, Óscar. Historia mínima de Cuba. Madrid: Turner, 2013. 